\title{
83. TECTONIC SYNTHESIS AND IMPLICATIONS OF JAPAN SEA ODP DRILLING ${ }^{1}$
}

\author{
Kensaku Tamaki, ${ }^{2}$ Kiyoshi Suyehiro, ${ }^{2}$ James Allan, ${ }^{3}$ \\ James C. Ingle, Jr., ${ }^{4}$ and Kenneth A. Pisciotto ${ }^{5}$
}

\begin{abstract}
Legs 127 and 128 completed drilling of six sites in the Japan Sea. Sites 795 and 796 are in the Japan Basin, Sites 794 and 797 in the Yamato Basin, Site 799 on the Yamato Rise, and Site 798 on the Oki Ridge. Basement was penetrated at Sites 794, 795 , and 797 where basaltic rocks were recovered. The ${ }^{40} \mathrm{Ar}-{ }^{39} \mathrm{Ar}$ absolute ages of these rocks are $17-24 \mathrm{Ma}$ at Site $795,20-21$ $\mathrm{Ma}$ at Site 794, and 18-19 Ma at Site 797, suggesting southward younging of the crust. Variations in chemical compositions and melting experiments suggest that the basin volcanism results from seafloor spreading or a continental rifting process. The borehole seismometer experiment at Site 794 indicates the crust is $12 \mathrm{~km}$ thick with the lower crust twice as thick as that of the Japan Basin. Eight discrete stages of basin subsidence history were derived from the comparative study of stratigraphy of the drilling sites and the surrounding offshore and onshore geological sections.

Analyses of these new data, together with more detailed identification of magnetic anomaly lineations in the Japan Basin, have yielded a tectonic scenario for the evolution of the Japan Sea. The entire Japan Sea was extending from $32 \mathrm{Ma}$ to $10 \mathrm{Ma}$, during which major opening associated with vigorous basin volcanism occurred about 28 to $18 \mathrm{Ma}$. The Japan Sea started its opening by crustal thinning within the proto-Japan arc. As thinning proceeded, breakup of the lithosphere was initiated at the major strike-slip fault forming the eastern margin of the juvenile sea, triggering seafloor spreading. Subsequent rifting and seafloor spreading process propagated southwestward during a period when the southern part of the Japan Sea was still undergoing crustal thinning, which ceased about $18 \mathrm{Ma}$ and left oceanic crust in its wake. This crust now forms the eastern floor of the Japan Basin. Thinned arc crusts and relic pieces of the upper crust of the proto-Japan arc were left in the southern part of the Japan Sea as deep sea basins and rises and ridges, respectively. Crustal thinning and propagating seafloor spreading of thinned crust are identified as the most significant processes for the opening of the Japan Sea.
\end{abstract}

\section{INTRODUCTION}

The western Pacific is unique in its abundance and concentration of marginal basins. More than $75 \%$ of world's marginal basins are distributed here from the Bering Sea in the north Pacific to the Tasman Sea in the south Pacific (Fig. 1). The western Pacific also contains the highest concentration of subduction zones in the world, demonstrating it constitutes the largest area of lithospheric plate consumption. The western Pacific plays a critically important role in earth dynamics and represents an important region in which to investigate the unresolved mechanisms responsible for the intimate co-occurrence of marginal basins and subduction zones.

The Japan Sea is located in a northern part of the western Pacific marginal basin swarm (Fig. 1). This marginal sea is contiguous to the Eurasia continent. The strategy for ODP drilling in the Japan Sea involved two mutually planned legs. Leg 127 targeted the drilling of the deep sea basins, whereas Leg 128 targeted the drilling on rises and ridges as well as geophysical experiments in the Yamato Basin. Sites 795 and 796 are in the Japan Basin, Sites 794 and 797 in the Yamato Basin, Site 799 on the Yamato Rise, and Site 798 on the Oki Ridge (Fig. 2). One of the major advantages of drilling in the Japan Sea was the large accumulation of geological and geophysical data from the Japan Sea proper and from the surrounding continental and insular areas. Pre-ODP data available included bottom sampling data, seismic reflection and refraction data, gravity and magnetic measurements, heat flow data, electromagnetic study, submersible observation of sea bottom, teleseismic crustal study including recent seismic tomogra-

${ }^{t}$ Tamaki, K., Suyehiro, K., Allan, J., McWilliams, M., et al., 1992. Proc. ODP, Sci. Results, 127/128, Pt. 2: College Station, TX (Ocean Drilling Program).

${ }^{2}$ Ocean Research Institute, University of Tokyo, Minamidai, Nakano, Tokyo 164, Japan.

${ }^{3}$ Ocean Drilling Program, Texas A\&M University, 1000 Discovery Drive, College Station, TX 77840, U.S.A.

${ }^{4}$ Department of Geology, Stanford University, Stanford, CA 94305-2115, U.S.A.

${ }^{5}$ BP Exploration Company Ltd., 4/5 Long Walk, Stockley Park, Uxbridge, Middlesex, UB11 1BP, United Kingdom. phy, and previous deep-sea drilling data from DSDP Leg 31. The crustal structure of the Japan Sea has been particularly well-studied by seismic refraction (e.g., Ludwig et al., 1975; Hirata et al. 1989). Consequently, the crustal structure of the Japan Sea is probably the better understood than any marginal basin in the world. Our understanding of the crustal structure was enhanced with data obtained from a borehole seismometer emplaced at Site 794 during Leg 128 (Shinohara et al., this volume). Based on published refraction results and new high resolution seismic data obtained at Site 794, we conclude that the crustal thinning process was fundamental to the formation of the Japan Sea.

Legs 127 and 128 had a variety of objectives including investigation of tectonics, magma genesis, paleoenvironment analysis, sedimentology, mineral ore deposit genesis, and downhole geophysical experiments. This paper summarizes the key evidence bearing on opening tectonics, timing of basin formation, and associated igneous activity. The most critical data needed to reconstruct basin formation and associated magma activity must be obtained from the basement rocks. Leg 127 penetrated into the basement at Sites 794, 795, and 797 (Fig. 3). Leg 128 further extended the penetration at Site 794 and deployed a borehole seismometer there for the study of crustal structure as well as the observation of earthquakes. Successful penetration of basement at three sites in the Japan Sea provided us with a complete basin history and allowed both the age of basement volcanism and the composition of basement rocks to be firmly established. In this paper, we combine our drilling results with the previously accumulated offshore and onshore data and summarize the opening of and basin formation in the Japan Sea.

\section{AGE OF BASEMENT}

\section{Overview}

Despite voluminous accumulated geological and geophysical data gathered from the Japan Sea and surrounding land areas, the age of formation of the Japan Sea has remained controversial (e.g., Tamaki, 1986). The uncertainty is due in large part to the complexity or poorly 


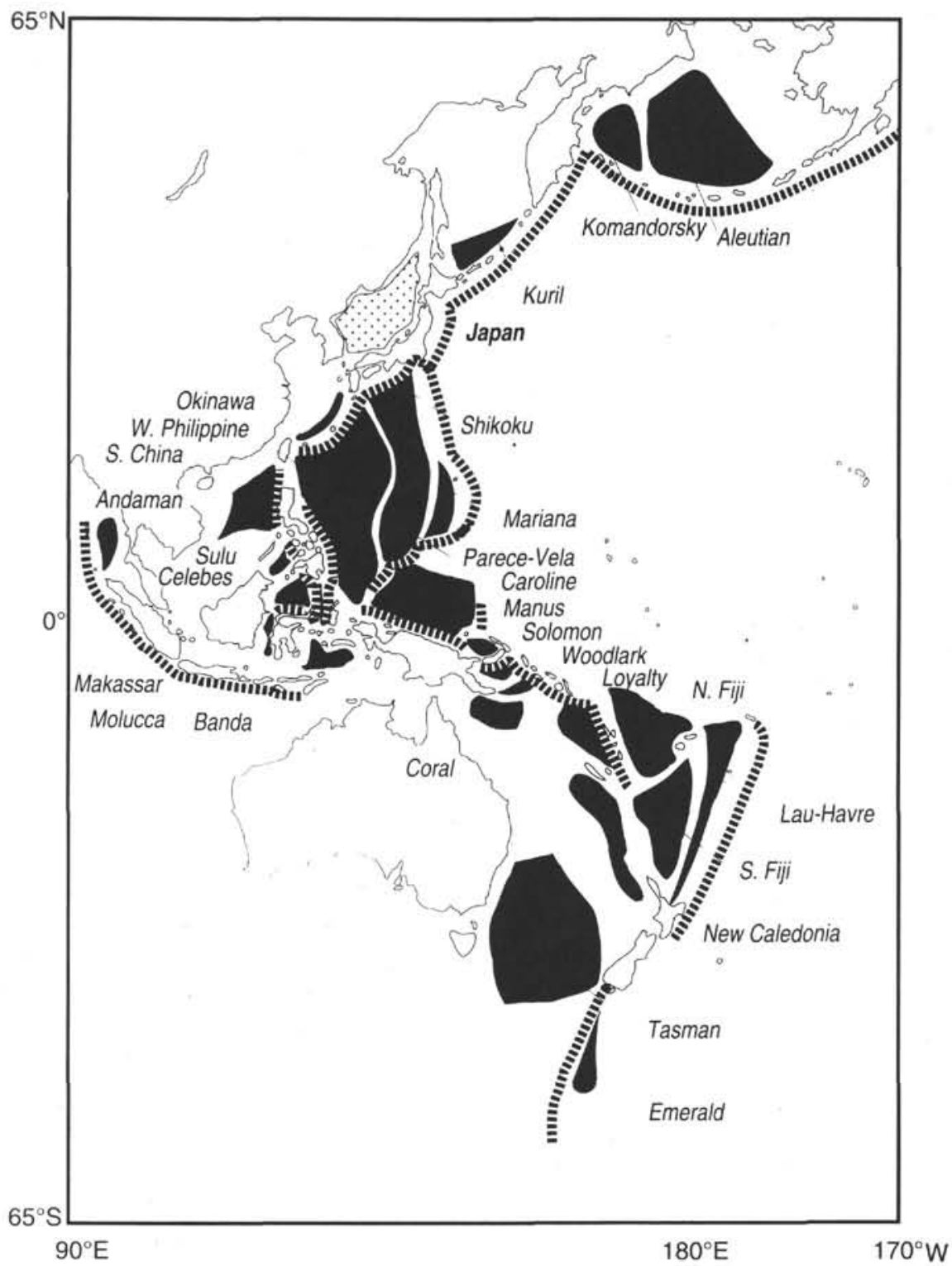

Figure 1. Marginal basins in the western Pacific (shaded) after Tamaki and Honza (1991). Dashed lines show trenches.

resolved magnetic anomalies in the Japan Sea (e.g., Isezaki, 1986). In contrast, the ages of most of the other marginal basins in the western Pacific have been successfully determined on the basis of identification of magnetic anomaly lineations. As discussed later, magnetic anomalies in the Japan Sea have been obscured due to localized distribution of oceanic crust and the broad distribution of thinned island-arc crust in the sea. However, recent detailed mapping (Kobayashi et al., 1986) has more clearly revealed anomaly patterns in the eastern part of the Japan Basin where Hirata et al. (1991) have also identified typical oceanic crust using seismic refraction.

DSDP Leg 31 (Karig, Ingle, et al., 1975) attempted to drill into the basement of both the Japan Basin and the Yamato Basin in 1973 (Fig. 2). Unfortunately, drilling had to be abandoned before reaching the basement because of safety considerations and a medical emergency. In addition, Leg 31 drilling did not penetrate deeply enough into the Neogene sediment blanket to reliably estimate the basement age through extrapolation of sediment accumulation rates (Tamaki, 1986), hence, the age of formation of the Japan Sea remained uncertain.
In the intervening years between DSDP Leg 31 and ODP drilling in 1989, paleomagnetic studies addressed the timing of opening of the Japan Sea. These data pointed to specific rotation of Honshu during middle Miocene time, and indicated that a sharp clockwise rotation of the southwest Japan occurred at $15 \mathrm{Ma}$ (Otofuji and Matsuda, 1983). These results strongly demonstrated that the opening of the Japan Sea occurred rapidly over a short interval from 16 to 14 Ma (Otofuji and Matsuda, 1987). The paleomagnetic evidence of rapid arc rotation attracted the attention of many researchers, especially in Japan, and many considered the age of the opening of the Japan Sea to be well established as $15 \mathrm{Ma}$. Alternatively, available heat flow data suggested that the crust beneath the Japan Sea must be older than $20 \mathrm{Ma}$ (Yamano, 1985; Tamaki, 1986). In addition, it was known that the depth of basement in the Japan Sea is comparable to that of the Shikoku Basin (24-15 Ma) and the South China Sea (32-17 $\mathrm{Ma}$ ), also suggesting an age of formation older than $15 \mathrm{Ma}$ (Tamaki, 1986). Thus, ODP drilling at Site 797 in the southern Yamato Basin was aimed in part at testing the hypothesis of rapid opening of the 


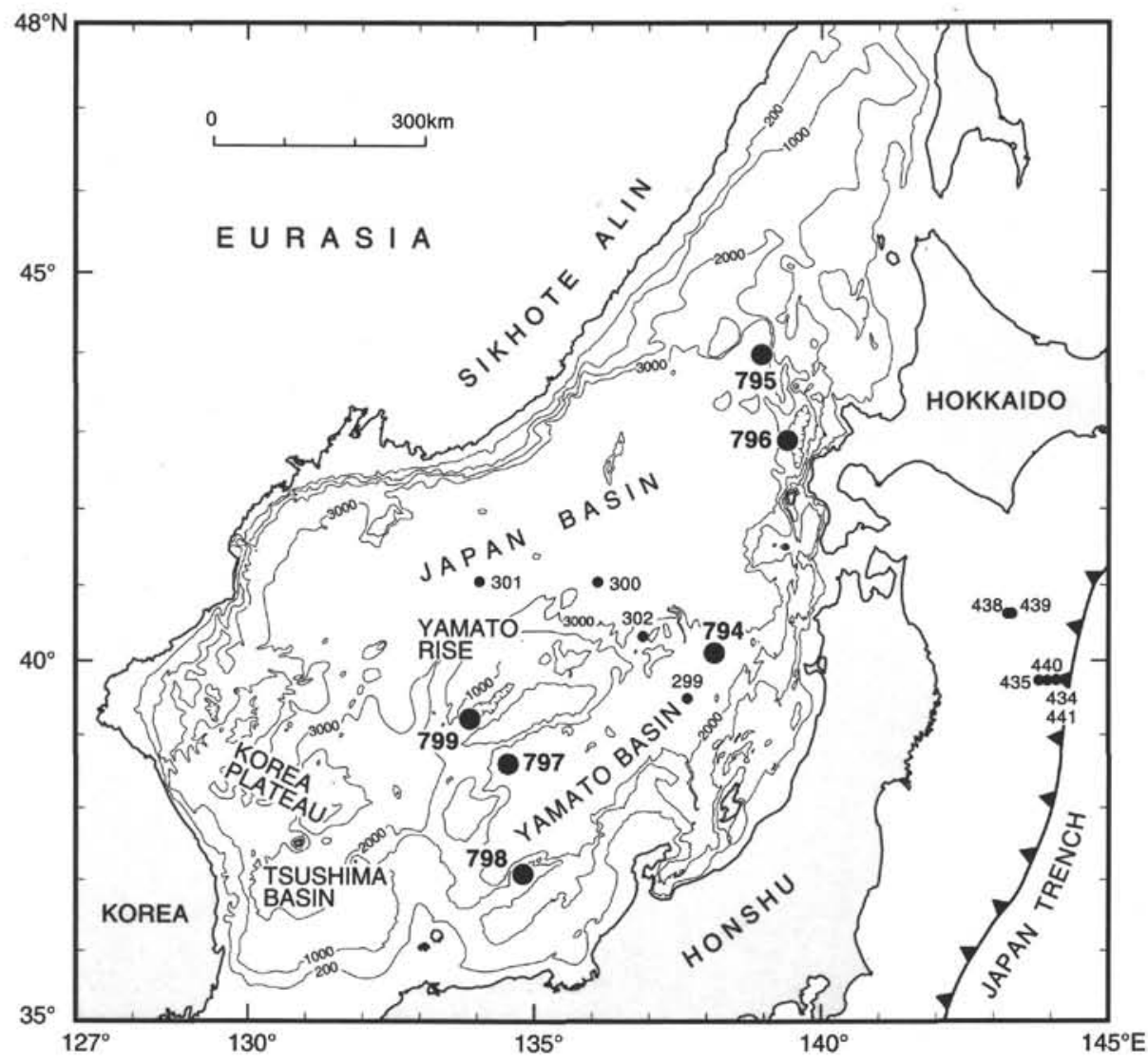

Figure 2. Deep sea drilling sites in the Japan Sea. Leg 31: Sites 299-302. Leg 127: Sites 794-797. Leg 128: Sites 794, 798, and 799. Bathymetry in meters.

Japan Sea and coincident rotation of southwest Japan. In contrast to the consistent data from southwest Japan, paleomagnetic data from the northern Japan arc (Tohoku district) were divergent, suggesting more complicated block rotation since the late Oligocene (Tosha and Hamano, 1988; Yamazaki, 1989).

Kaneoka (1990) summarized all published radiometric age data obtained from analyses of submarine rock samples recovered from the sea bottom of the Japan Sea. Samples especially critical to estimating the age of basin formation were dredged from volcanic seamounts or lava flows on the Yamato Rise. Using these data, Kaneoka (1990) estimated the age of the opening of the Japan Sea at $17-25 \mathrm{Ma}$, in contrast to that suggested by the paleomagnetic data. Pre-ODP estimates of the age of formation of the Japan Sea based on onshore geological data were even more divergent and ranged from 10 to $50 \mathrm{Ma}$ (Tamaki, 1988).

The divergence in estimated ages for the formation of the Japan Sea was a major obstacle to the proper study of the tectonic processes responsible for the opening of the sea. A comprehensive synthesis of the tectonic evolution of the Japan Sea simply could not commence without a confirmed age of opening.

\section{RESULTS}

Basement penetration at Sites 794, 795, and 797 provided us with several opportunities to evaluate and estimate the initial age of basin formation in the Japan Sea. At each of these sites, the biostratigraphic data from sediments overlying volcanic basement were used to estimate the initiation timing of the basin subsidence and formation. In addition, radiometric dates obtained on the basaltic rocks forming the basement sequences provided constraints on the age and duration of basin volcanism associated with basin formation.
The ages of older sediments at our ODP sites were exclusively determined using biostratigraphic techniques as summarized by Burckle et al. (this volume). However, biostratigraphic age determinations of these sediments proved to be rather difficult despite the systematic analysis of six groups of microfossils; diatoms, planktonic foraminifers, benthic foraminifers, calcareous nannofossils, radiolarians, spores, and pollen. Diatoms, planktonic foraminifers, and calcareous nannofossils are the most effective groups for age determination in Japan Sea sediments because their biostratigraphy is well established in this area. Of the latter three groups, diatoms offer the most precise biostratigraphic age control. Unfortunately, the wholesale dissolution of diatoms below the opal-A/opal-CT boundary at most sites (Tamaki, Pisciotto, Allan, et al., 1990) precluded the application of this group to dating the lowermost sediments in any given hole. At Site 795, however, a few diatoms were preserved below the opal-A/opal-CT boundary in dolomite nodules and assisted in estimating an age for these sediments (Koizumi et al., this volume).

Sporadic but important occurrence of calcareous nannofossils (Rahman, this volume) and planktonic foraminifers (Brunner, this volume) provided critical age information on the sediments close to the basement. The usefulness of these latter groups in middle and lower Miocene sediments of the Japan Sea region is enhanced by increased diversities associated with the warm climate phase coincident with the period of formation of the Japan Sea. In addition, Rahman (this volume) improved nannofossil age determinations through the identification of additional species during post-cruise analyses. Pollen biostratigraphy (Yamano, this volume) provides a critical constraint on the age of basal sediments at Site 797 with floras just above the uppermost basaltic unit determined to represent an age of 17-18.5 Ma. In addition, Tada and lijima (this volume) and Meredith and Tada (this volume) illustrate that the rhythmic stratifi- 


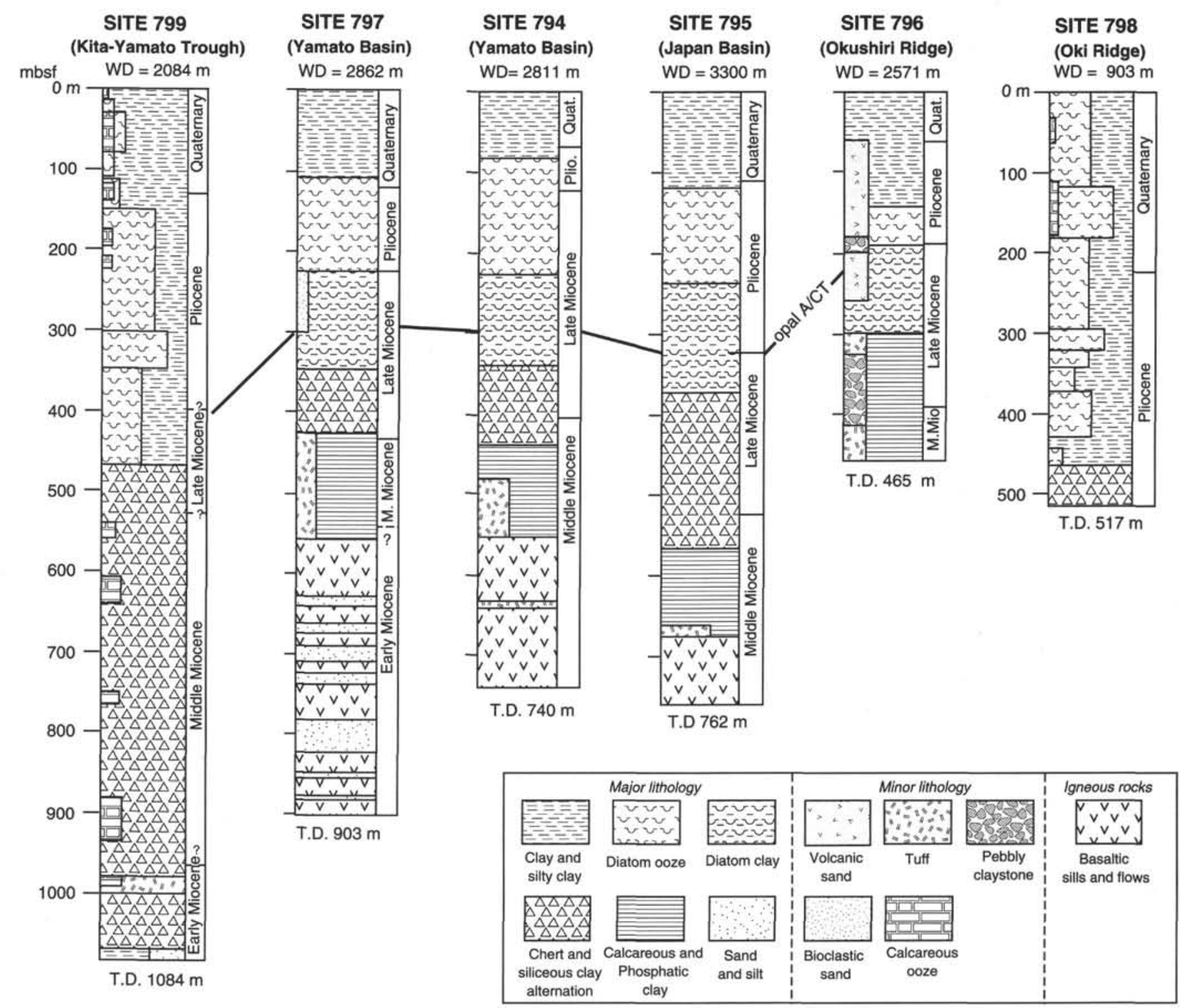

Figure 3. Columnar sections of drilling sites of Legs 127 and 128.

cation inherent to Miocene cherts and siliceous shales may allow precise correlation between Sites 794 and 797. In summary, the application of available biostratigraphic data and derived sediment accumulation rates yielded the following estimated ages for the sediments just above basaltic basement rocks as follows; Site 794, 15-16 Ma; Site 795, 13-15 Ma; and Site 797, 17-18.5 Ma (Burckle et al., this volume).

Penetration into basement rocks in the Japan Sea varied as follows: $200 \mathrm{~m}$ at Site 794, $80 \mathrm{~m}$ at Site 795, and $350 \mathrm{~m}$ at Site 797. Although basaltic rocks were encountered at all three sites, the lithology varied. At Site 794, a $1.5 \mathrm{~m}$ layer of sediments was recovered at $100 \mathrm{~m}$ below the top of the basalt sequence, and 10-30 m dolerite sills were observed (Tamaki, Pisciotto, Allan, et al., 1990). At Site 797 acoustic basement was characterized by a thick sequence of basaltic sills, flows, and intercalated sediments (Fig. 3), suggesting concurrent deposition of sediment and igneous activity. Among the 21 basaltic units recovered at Site 797, the upper 9 units are more primitive in composition, whereas the lower 12 units are rather enriched, suggesting two distinct basaltic eruptions as described in the next section. In contrast, only basaltic rocks were encountered during basement drilling at Site 795.

The basalts recovered at Sites 794, 795, and 797 were dated by the ${ }^{40} \mathrm{Ar}-{ }^{39} \mathrm{Ar}$ method. Although two groups of basalts were identified at Site 797, no samples from the upper group were subjected to radiometric analysis because of their low K content (Kaneoka et al., this volume). The ${ }^{40} \mathrm{Ar}-{ }^{39} \mathrm{Ar}$ method generally yields accurate ages for marine volcanic rocks because it is considered to be rather free from the problem of excess and/or loss of ${ }^{40} \mathrm{Ar}$ and $\mathrm{K}$ addition by the alteration by seawater (Kaneoka, 1986). Kaneoka et al. (this volume) succeeded in obtaining reliable radiometric ages for basalts at Sites 794 and 797 in the Yamato Basin. Less reliable results were obtained from Site 795 in the Japan Basin. Three reliable measurements at Site 794 yielded ages ranging from 19.9 to $21.2 \mathrm{Ma}$ whereas the ages obtained at Site 797 range from 17.7 to $19.0 \mathrm{Ma}$. The less reliable ages determined for Site 795 range from 17.1 to $23.7 \mathrm{Ma}$. Overall, the range of radiometric obtained from Sites 794, 795, and 797 falls between $17 \mathrm{Ma}$ and $24 \mathrm{Ma}$ ages and hence encompasses almost the entire early Miocene. 
Figure 4 is a comparative summary of the age estimates for basement rocks recovered at ODP Sites 794, 795, and 797. There are no significant discrepancies between the radiometric ages and biostratigraphically determined ages for these sites. The estimated ages of sediments are everywhere younger than or identical with the radiometric ages of the underlying basalts. At Site 797 the biostratigraphic age estimated for sediments overlying the uppermost basalts and the radiometric age of the basalts are nearly coincident. In turn, age coincidence at this contact implies that the basalts at Site 797 were rapidly emplaced into the overlying sedimentary cover, a situation similar to that prevailing at modern sedimented ridges and spreading centers as revealed by ODP Leg 139 drilling on the Juan de Fuca Ridge (ODP Leg 139 Scientific Drilling Party, 1992) and by DSDP Leg 64 drilling in the Guaymas Basin (Curray, Moore, et al., 1982). The coincidence of the radiometric and biostratigraphic ages at Site 797 also demonstrates that the ${ }^{40} \mathrm{Ar}-{ }^{39} \mathrm{Ar}$ age determinations are valid despite the pervasive alteration, and indirectly support the reliability of ${ }^{40} \mathrm{Ar}-{ }^{39} \mathrm{Ar}$ ages obtained at Sites 794 and 795.

At Site 794 the radiometric ages of basement basalts are several million years older than overlying sediments. A hiatus may be present at or near the basalt/sediment contact, which might have been caused by the massive intrusion of the sills at Site 794 which scraped off sediments during this process. The oldest radiometric age of $24 \mathrm{Ma}$ obtained for any of the basalts analyzed was found at Site 795 in the Japan Basin. However, Kaneoka et al. (this volume) note that this age may be less reliable than the radiometric ages obtained from basalts at Sites 794 and 797. Again, a hiatus is indicated at or in sediments just above the basalt/sediment contact at Site 795 . Site 795 is located on a basement high. Seismic profiles suggest that sediments onlap the high, which may explain the absence of older sediment at the base of the sediment column at Site 795.

As discussed above, we believe that the radiometric ages obtained by ${ }^{40} \mathrm{Ar}-{ }^{39} \mathrm{Ar}$ method are generally reliable. The basement rocks of the Yamato Basin are characterized by ages ranging from 18 to $21 \mathrm{Ma}$, suggesting basin-wide volcanism during this period. The slight difference in ages between basalts at Sites 794 and 797 may have special significance as discussed later in this summary. In contrast, Kaneoka et al. (1991) reported the ${ }^{40} \mathrm{Ar}-{ }^{39} \mathrm{Ar}$ age of 32.7 Ma for the basaltic rock collected by submersible from a fault scarp on the slope of Okushiri Ridge. Because the Okushiri Ridge may constitute an uplifted (obducted) piece of Japan Basin crust (Tamaki and Honza, 1985), it is possible that the age of the Japan Basin is older than that of the Yamato Basin, as also inferred by the radiometric date of $24 \mathrm{Ma}$ obtained on basement basalts at Site 795 .

\section{TECTONIC SIGNIFICANCE OF BASEMENT IGNEOUS ROCKS}

\section{Overview}

In addition to the age of basin formation, the basement igneous rocks hold clues to the mantle dynamics related to the opening of the Japan Sea. In this section we summarize the key findings from the shipboard and post-cruise research and discuss the magma genesis accompanying the opening of the Japan Sea.

Basement samples from Sites 794, 795, and 797 have been thoroughly investigated, with results presented in this volume. Specific topics include mineralogy (Thy, this volume, chapter 52; Allan, this volume), rock alteration (Allan, this volume; Allan and Gorton, this

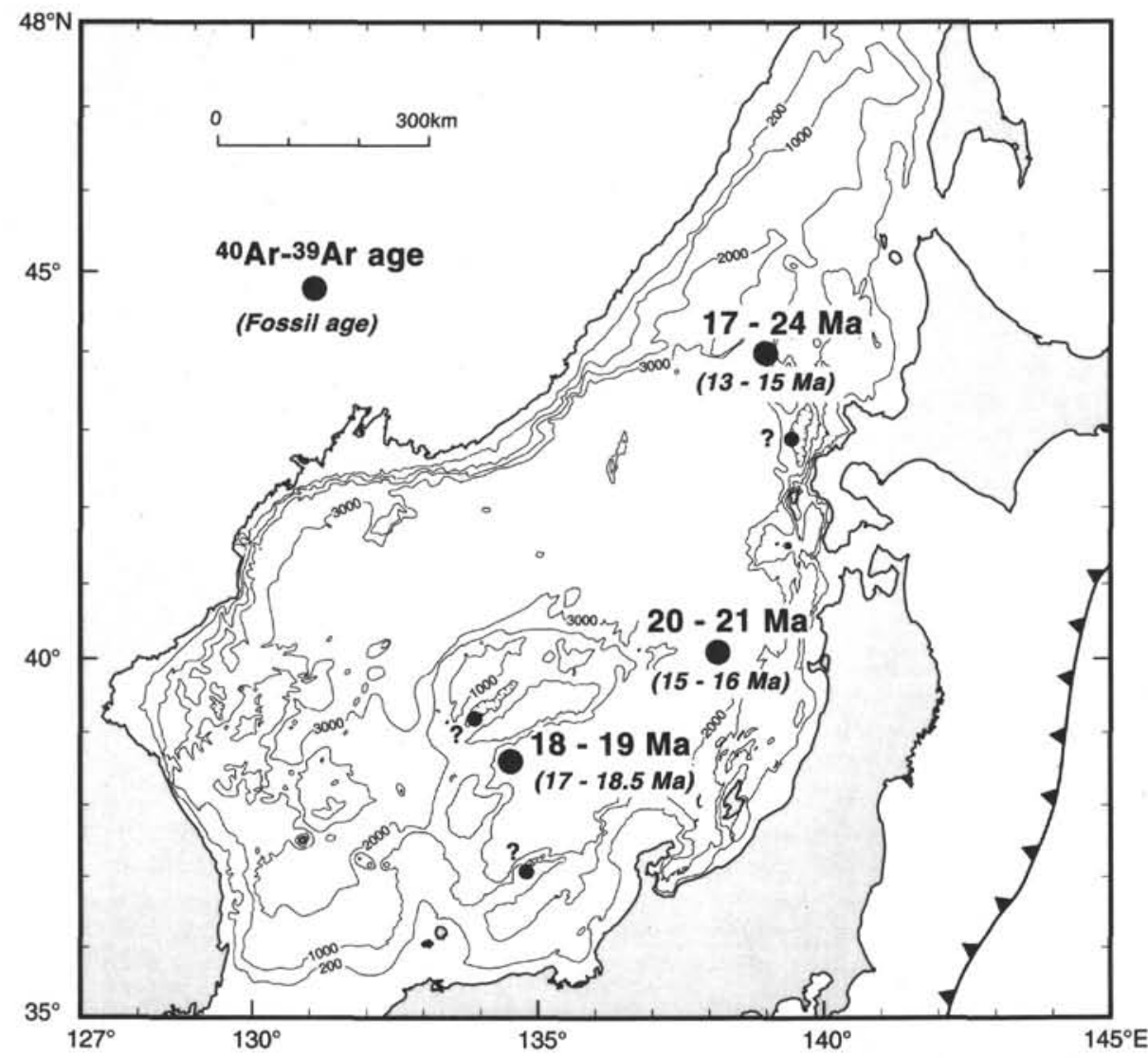

Figure 4. Age of basement basalts determined by ${ }^{40} \mathrm{Ar}^{-39} \mathrm{Ar}$ radiometric analyses (Kaneoka et al., this volume) as well as with the estimated age of the sediments (in parentheses) overlying the basement basalts at three sites (Sites 794, 795, and 797) (Burckle et al., this volume). 
volume), geochemistry (Allan and Gorton, this volume; Pouclet et al., this volume); isotopic studies (Cousens and Allan, this volume; Pouclet et al., this volume; Nohda et al., this volume), radiometric age determinations (Kaneoka et al., this volume; Pouclet et al., this volume), and experimental petrology (Thy, this volume, chapters 53 and 54; Yamashita et al., this volume).

Interpretation of these intrusive and extrusive rocks has proved to be problematic, due to the extensively altered nature of most of the samples, as detailed in Allan (this volume), Allan and Gorton (this volume), Tamaki, Pisciotto, Allan, et al. (1990), and Ingle, Suyehiro, von Breymann, et al. (1990). Most units sampled represent basaltic magmas intruded into water-saturated, unconsolidated sediments, with extensive hydrothermal alteration during and immediately after emplacement. Other samples representing erupted lava flows also exhibit moderate to pronounced alteration to secondary minerals. In addition, there is a later diagenetic alteration during the $20 \mathrm{Ma}$ or so since emplacement which particularly affects thin units and unit margins. Generally, the intensity of alteration increases going from core to rim, with the large-ion lithophile elements (LILE), $\mathrm{Ca}, \mathrm{Sr}$, and $\mathrm{Mg}$ being most strongly affected.

Allan (this volume) used the compositions of relict $\mathrm{Cr}$-spinel in altered unit margins to predict original magmatic $\mathrm{Mg} /\left(\mathrm{Mg}+\mathrm{Fe}^{2+}\right)$, and found that this ratio had been substantially raised by alteration even in some of the freshest unit interiors. As a result, the use of standard petrological tools such as Harker diagrams, the calculation of normative compositions, and the application of liquid line-of-descent calculations are of questionable relevance for all but the freshest samples. This problem of "seeing through" the alteration is profound, and must be considered when interpreting geochemical, $\mathrm{Sr}$ isotopic, and ${ }^{40} \mathrm{Ar} /{ }^{39} \mathrm{Ar}$ radiometric data. At the same time, the good to excellent recovery of coherent but variably-altered units in cores offers a unique opportunity to study the mobility of elements during alteration (Allan and Gorton, this volume). Differences of interpretation and rock classification between the contributing authors are partially caused by this alteration.

\section{Site 795}

Site 795 recovered three units of pervasively altered, brecciated to massive basalt, basaltic andesite, and andesite of middle Miocene age (Kaneoka et al., this volume; Tamaki, Pisciotto, Allan, et al., 1990). These samples are characterized by plagioclase and clinopyroxene phenocrysts and the lack of olivine. The character of the overlying sediments indicates that the igneous rocks were erupted well below wavebase, and the highly vesicular nature of the lavas suggests that they were erupted at $1000 \mathrm{mbsf}$ or less, contained a high volatile content, or both (Tamaki, Pisciotto, Allan, et al., 1990). Representative major- and trace-element whole-rock analyses are given in Allan and Gorton (this volume).

Thy (this volume, chapter 52) found that the clinopyroxenes (cpx) contain low amounts of $\mathrm{Cr}$ and $\mathrm{Ti}$. Additionally, the cpx has high $\mathrm{Mg} /(\mathrm{Mg}$ $+\mathrm{Fe}^{2+}$ ), consistent with early crystallization of this phase. This mineralogy of the Site 795 lavas is typical of calc-alkaline and arc tholeiite suites, and $\mathrm{Fe}$ and $\mathrm{V}$ depletion and $\mathrm{Al}$ and $\mathrm{Si}$ enrichment trends in the basaltic andesites and andesites indicate a calc-alkaline liquid line of descent (Tamaki, Pisciotto, Allan, et al., 1990). When compared to normal mid-ocean ridge basalt (N-MORB; Fig. 5), the Site 795 samples are characterized by slight enrichments in the large-ion lithophile elements (LILE), light rare earth elements (LREE), andP, and contain slight relative depletions of the high-field-strength elements (HFSE) such as Ta and $\mathrm{Nb}$ (Allan and Gorton, this volume). These relative enrichments and depletions are all consistent with derivation of the samples from a mantle source similar to that of a low-K oceanic volcanic arc or backarc; derivation from a continental arc source would yield substantially larger relative elemental enrichments and depletions (Allan and Gorton, this volume; Pearce et al., 1981; Saunders and Tarney, 1984; Wilson, 1989; Hawkins et al., 1990).

The isotopic data are consistent with an arc-related genesis (Fig. 6 ), with ${ }^{87} \mathrm{Sr} /{ }^{86} \mathrm{Sr}$ more radiogenic and ${ }^{143} \mathrm{Nd} /{ }^{144} \mathrm{Nd}$ less radiogenic than MORB (Cousens and Allan, this volume; Nohda et al., this volume). Cousens and Allan (this volume) interpreted the isotopic data to reflect incorporation of subducted sediment into a depleted

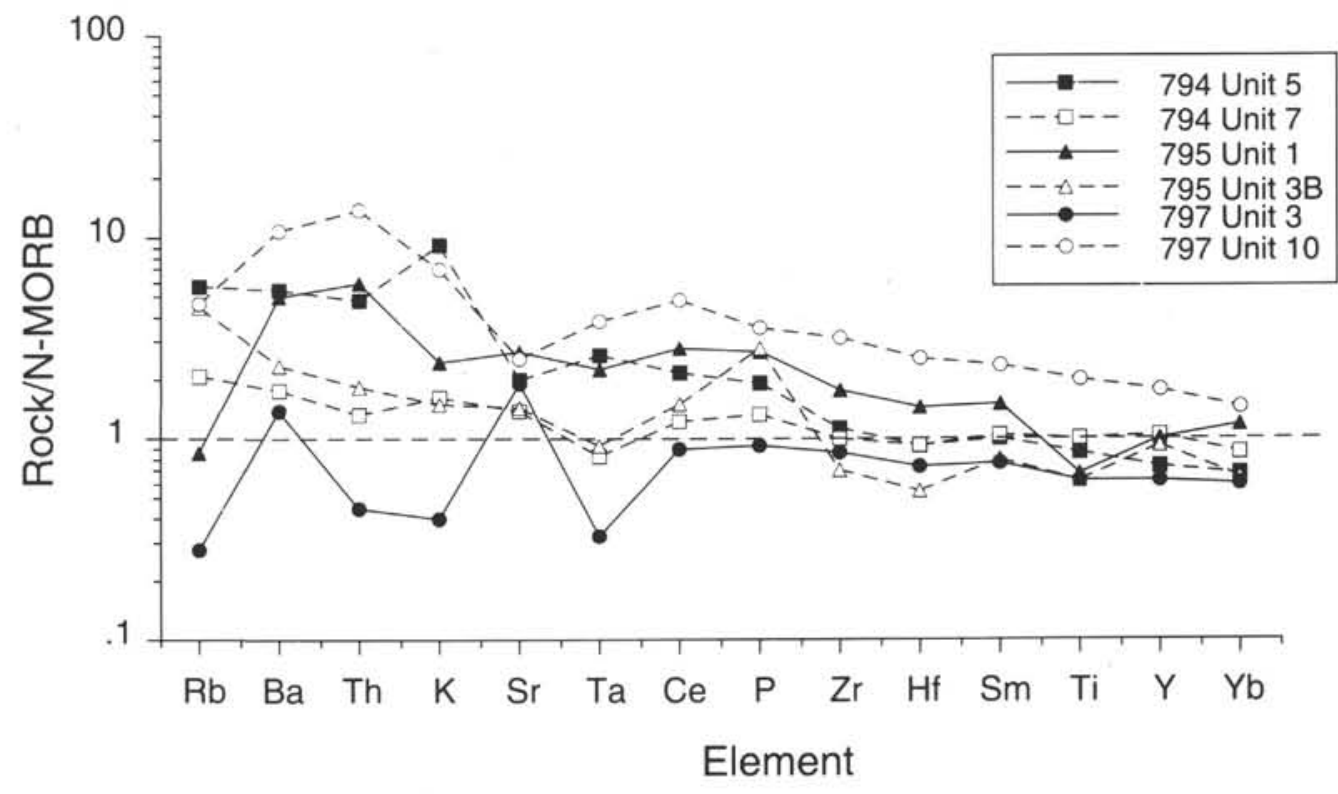

Figure 5. N-MORB (normal mid-ocean ridge basalt) normalized compositions of representative samples from Legs 127 and 128, with normalizing values from Pearce et al. (1981). Horizontal dashed line shows representative N-MORB composition. Even though the freshest possible examples were used, $\mathrm{Rb}, \mathrm{Ba}$, and $\mathrm{K}$ values have likely been changed due to alteration and so should be considered with caution. Data are from Allan and Gorton (this volume) and Tamaki, Pisciotto, Allan, et al. (1990) and are consistent with data from Pouclet and Bellon (this volume). 
mantle wedge overlying a subduction zone. The isotopic, geochemi$\mathrm{cal}$, and mineralogical data are all consistent with the petrogenesis of the Site 795 lavas in a subaqueous oceanic volcanic arc, with volcanism occurring either within the arc or the backarc.

\section{Site 794}

Legs 127 and 128 recovered 10 moderately to totally altered igneous stratigraphic units as defined by the shipboard parties (Tamaki, Pisciotto, Allan, et al., 1990; Ingle, Suyehiro, von Breymann, et al., 1990). Subsequent studies integrating the results of Holes 794C and 794D have reallocated unit designations (Pouclet et al., this volume) into seven eruptive units, but geochemical and core recovery evidence was not considered sufficient by Allan and Gorton (this volume) to integrate confidently the site stratigraphy. To avoid confusion, our discussion will retain the original stratigraphic designations as they were mapped in core by both shipboard parties. A related, unresolved question is whether the Site 794 units all represent basaltic magmas intruded as sills into soft, tuffaceous sediment (Tamaki, Pisciotto, Allan, et al., 1990) or whether they represent a mixture of basaltic sills and lava flows (Ingle, Suyehiro, von Breymann, et al., 1990; Pouclet et al., this volume). Previous reports of sediment-sill complexes from DSDP and ODP legs have also been questioned, with revisionist interpretation given that they represent lava flows with diagenetic overprints at their margins (Gibson and Saunders, 1990). Nevertheless, the evidence of welded and baked sediment margins overlying coarse, thick igneous bodies is compelling evidence for intrusion of many Site 794 units.

Most units from Site 794 show a quench mineralogy of olivine + plagioclase $\pm \mathrm{Cr}$-spinel, with some being of relatively primitive nature (see analyses in Allan and Gorton, this volume; Pouclet and Bellon, this volume). Their interiors are coarse aphyric basalt or dolerite. In contrast, the uppermost 2 units (Unit 1 of Pouclet and Bellon, this volume) comprise an evolved, thick sill or laccolith which lacks olivine and is dominated by highly calcic plagioclase phenocrysts (Thy, this volume, chapter 52). Thy (this volume, chapter 53) argued that the lack of olivine, the abundance of anorthite-rich plagioclase, and the low $\mathrm{FeO}$ and high $\mathrm{Al}_{2} \mathrm{O}_{3}$ (over $21 \%$ in whole-rock analyses) in the whole rock composition (see Allan and Gorton, this volume) implied that this unit was volatile-enriched and underwent a calcalkaline liquid line of descent.

Geochemical and mineralogical studies show considerable variation in rock chemistry, with lower (Leg 127 Units 1-5, Leg 128 Units 1-4) and upper complexes (Leg 128 Units 6-9) defined on the basis of their REE and HFSE geochemistry (Allan and Gorton, this volume; Pouclet and Bellon, this volume; and Ingle, Suyehiro, von Breymann, et al., 1990, define Unit 6 as a Middle Volcanic Unit of intermediate character). The upper complex (Unit 5 in Fig. 5) is substantially enriched in the LILE and LREE relative to N-MORB, and shows no relative depletions in the HFSE such as $\mathrm{Ta}$ and $\mathrm{Nb}$. Their N-MORB normalized patterns are somewhat similar to those of T-MORB (Sun et al., 1979). The lower complex contains substantially lower amounts of incompatible elements, having compositions more similar to that of N-MORB with small relative depletions in the HFSE such as Ta (Unit 7 in Fig. 5). All rocks have flat chondrite-normalized medium to heavy rare-earth patterns (MREE to HREE; Allan and Gorton, this volume). No variation in isotopic composition with chemical composition was noted for the Site 794 rocks, with all samples showing similar values (Fig. 6; Cousens and Allan, this volume; Nohda et al., this volume; Pouclet and Bellon, this volume). Like the Site 795 rocks, samples from Site 794 are more radiogenic in ${ }^{87} \mathrm{Sr} /{ }^{86} \mathrm{Sr}$ and less radiogenic in ${ }^{143} \mathrm{Nd} /{ }^{144} \mathrm{Nd}$ than MORB, and plot above the northern hemisphere reference line in $\mathrm{Pb}$ isotopic composition (NHRL; Zindler and Hart, 1986; Hart, 1987). Although the coherent variation with stratigraphy implies an age-related progression in chemistry, the radiometric ages of the two complexes are unresolvable within analytical error, centering around $20 \mathrm{Ma}$ (Kaneoka et al., this volume; Pouclet and Bellon, this volume). The units as a whole are roughly similar to middle Miocene basalt flows and sills from the Akita-Yamagata oil fields, except that none contain a Ca-poor pyroxene (Tsuchiya, 1988, 1989, and 1990). Their overall compositions fall within the more enriched range shown by other tholeiites from backarc basins (Saunders and Tarney, 1984; Pearce et al., 1981; Volpe et al., 1987).

\section{Site 797}

Leg 127 recovered 21 basaltic units at Site 797 in two spatially defined groups-a more primitive upper group of 9 sills, dikes, and lava flows of basalt which are poor in incompatible elements, and a more evolved lower group of 12 sills of basalt which are enriched in incompatible elements (Tamaki, Pisciotto, Allan, et al., 1990). The upper group has been classified as calc-alkaline basalts (Thy, this volume, chapter 53) or high-Al basalts (Tamaki, Pisciotto, Allan, et al., 1990; Yamashita and Fujii, this volume), based on high $\mathrm{Al}_{2} \mathrm{O}_{3}$, the lack of significant $\mathrm{FeO}$ enrichment and $\mathrm{Al}_{2} \mathrm{O}_{3}$ depletion trends against $\mathrm{MgO}$, or both. However, the degree of alteration in many of these units makes this interpretation problematic, and fresher samples resemble tholeiites in composition (Allan and Gorton, this volume). This inference is supported by experimental work; at $1 \mathrm{~atm}$, Thy (this volume, chapter 53) found a typically tholeiitic liquidus mineral assemblage of olivine + plagioclase for Unit 3. Despite the apparent primitiveness of Unit 3 (Ni, 160 ppm; Cr, 220 ppm; MgO, 9.8\%; Tamaki, Pisciotto, Allan, et al., 1990), the high-pressure experiments of Yamashita and Fujii (this volume) showed that it had undergone substantial olivine fractionation from a picritic parent. They found that plagioclase was a liquidus mineral up to $13 \mathrm{kbar}$, speculating that the high $\mathrm{Al}_{2} \mathrm{O}_{3}$ rocks from Sites 797 and 794 could have resulted from plagioclase accumulating during ascent after crystallization. This latter inference is supported by a positive Eu anomaly (actual $\mathrm{Eu}>$ expected Eu based on overall REE composition) in the samples (Allan and Gorton, this volume). Yamashita and Fujii (this volume) further inferred that the picritic parental melt was generated at about $14 \mathrm{kbar}$ from melting of spinel lherzolite, consistent with its flat, chondrite-normalized MREE to HREE patterns (Allan and Gorton, this volume).

The upper nine units at Site 797 are strongly depleted in the incompatible elements, with lower amounts of REE, HFSE, and most LILE than N-MORB (see Unit 3 in Fig. 5). The relative depletions in the HFSE Ta, $\mathrm{Nb}, \mathrm{Zr}$, and $\mathrm{Hf}$ are pronounced, and with the relative enrichment in $\mathrm{Sr}$ constitute a geochemical arc signature (Allan and Gorton, this volume). Isotopic signatures are less radiogenic in ${ }^{87} \mathrm{Sr} /{ }^{86} \mathrm{Sr}$ and more radiogenic in ${ }^{143} \mathrm{Nd} /{ }^{144} \mathrm{Nd}$ than the other Leg 127 and 128 samples measured, more closely approaching typical MORB values (Fig. 6; Cousens and Allan, this volume; Nohda et al., this volume). Backarc basin basalts with similarly low amounts of the LILE are found from the Lau Basin (Hawkins and Melchior, 1985; Ernewein et al., in press).

The lowermost 12 units are very different in composition, being more evolved (lower $\mathrm{MgO}, \mathrm{Ni}$, and $\mathrm{Cr}$ ), substantially more enriched in the incompatible elements, and showing only slight or no relative depletions in MORB-normalized HFSE such as Ta (Fig. 5). These aphyric units are typically heavily altered and were interpreted initially as representing enriched tholeiites and alkali basalts based on high $\mathrm{K}_{2} \mathrm{O}$ and $\mathrm{Ce}$ (Tamaki, Pisciotto, Allan, et al., 1990). Thy (this volume, chapters 53 and 54) found that this lower, enriched group could be derived by low-pressure fractionation of olivine and plagioclase (tholeiitic liquid line of descent) from a parental magma sharing major element characteristics to the overlying Unit 3 but more enriched in the incompatible elements. The moderate $\mathrm{Sr}$ contents, relatively low $\mathrm{CaO}$ and $\mathrm{Al}_{2} \mathrm{O}_{3}$ contents, and the mild negative Eu anomaly are consistent with partial derivation by plagioclase fractionation 

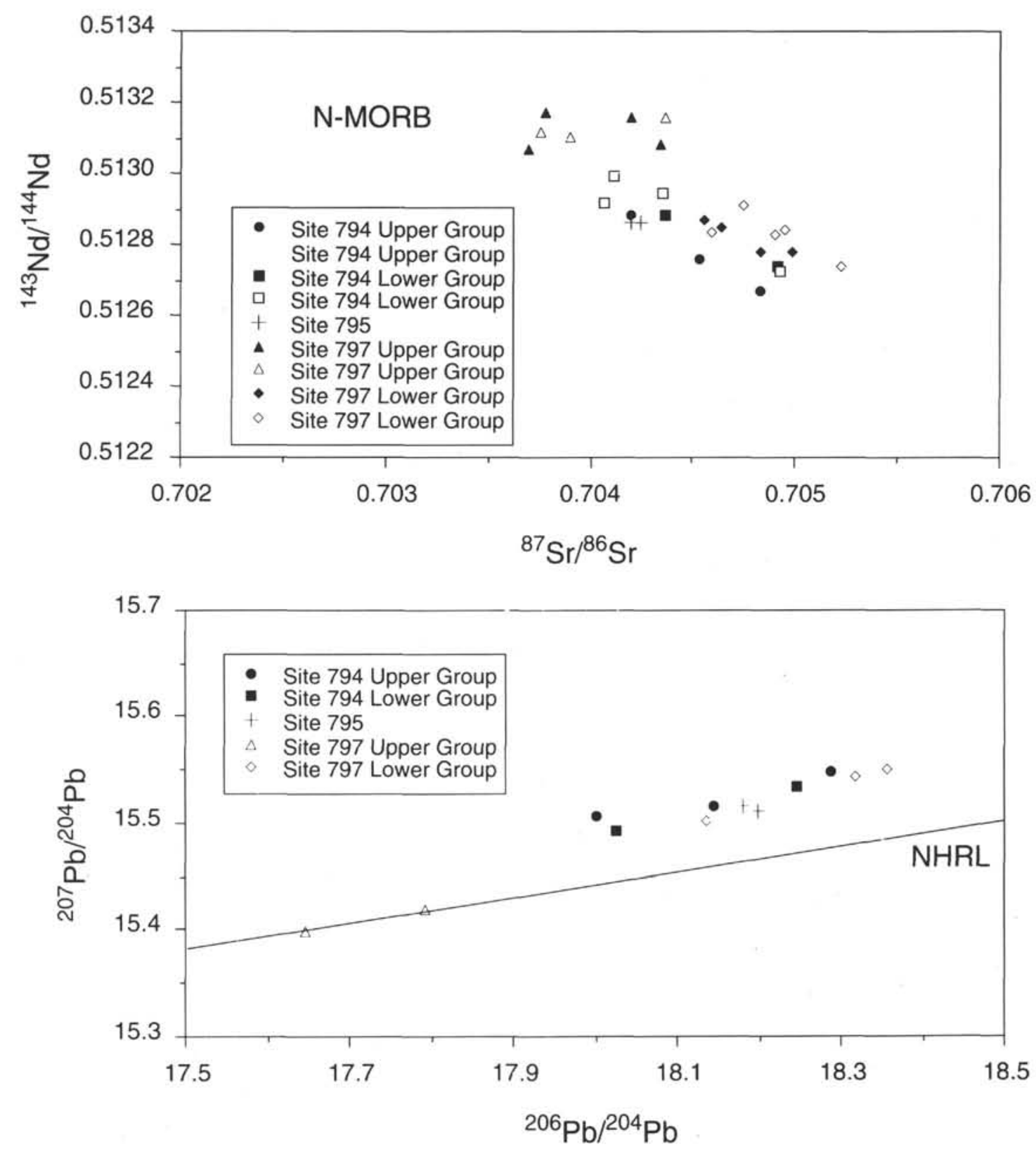

Figure 6. Isotopic compositions of Leg 127 and 128 samples. $\mathrm{Pb}$ isotopic data are from acid-leached samples reported by Cousens and Allan (this volume); for consistency, $\mathrm{Sr}$ and $\mathrm{Nd}$ isotopic data from acid-leached samples (Cousens and Allan, this volume; Nohda et al., this volume) are shown in solid symbols (those from Site 795 are acid-leached), with data from unleached samples (Nohda et al., this volume; Pouclet and Bellon, this volume) shown in open symbols. Also shown is the approximate average of N-MORB and the Northern Hemisphere Reference Line (compositions of both are from Hart, 1988; Zindler and Hart, 1986).

(Allan and Gorton, this volume). Due to uncertainties of the actual magmatic $\mathrm{K}_{2} \mathrm{O}$ value, it is probably more correct to refer to the entire lower group as enriched tholeiites.

As a group, these samples contain substantially more $\mathrm{Ta}, \mathrm{Nb}$, and $\mathrm{Ti}$ and substantially less $\mathrm{Sr}$ than typical arc basalts, and are more enriched in the incompatible elements (especially the HFSE) than most backarc basin basalts (Allan and Gorton, this volume; Wilson, 1989; Saunders and Tarney, 1984; Pearce et al., 1981). They fall within the range exhibited by the Akita-Yamagata basalts (Tsuchiya, 1990) and are similar to samples from Guaymas Basin (Saunders et al., 1982) and to intraplate basalts and transitional MORB (but with somewhat lower HFSE contents, e.g., Wilson, 1989; Pearce et al.,
1982). Consistent with their more enriched composition, the lower group of units has substantially more radiogenic ${ }^{87} \mathrm{Sr} /{ }^{86} \mathrm{Sr}$ and $\mathrm{Pb}$ isotopes and less radiogenic ${ }^{143} \mathrm{Nd} /{ }^{144} \mathrm{Nd}$ (Fig. 6; Cousens and Allan, this volume; Nohda et al., this volume). As at Site 794, the sharp demarcation in unit geochemistry with stratigraphic position implies an age-related progression in magma chemistry.

\section{Magma Genesis}

There are several critical features of the igneous rocks recovered from the Yamato Basin. The first is that the majority of units represent sills or dikes intruded during crustal extension into soft, rapidly 
deposited sediments associated with rapid subsiding of the basin (Tamaki, Pisciotto, Allan, et al., 1990). Therefore, the igneous rocks sampled by Legs 127 and 128 are almost certainly associated with the opening of the Yamato Basin.

The wide range in chemistry and isotopic composition exhibited by the samples from Sites 794 and 797 indicates that a variety of parental magmas derived from different and compositionally heterogeneous mantle sources was required to produce the range of igneous units sampled at each site (Fig. 7; Allan and Gorton, this volume; Cousens and Allan, this volume; Pouclet and Bellon, this volume; Nohda et al., this volume; Yamashita and Fujii, this volume; Thy, this volume, chapter 54). Like other backarc basin basalts (Wilson, 1989; Saunders and Tarney, 1984), they are intermediate in character between arc basalts, MORB, and intra-plate basalts, thereby defying easy classification of rock type. The relatively flat chondrite-normalized MREE to HREE patterns of the Yamato Basin samples (Allan and Gorton, this volume; Pouclet and Bellon, this volume) and the experimental data of Yamashita and Fujii (this volume) indicate that their sources were primarily shallow, with last equilibration and segregation of primary melt from mantle at pressures below that of lower stability of garnet (10-25 kbar).

A key finding from post-cruise research is that the magma sources in the Yamato Basin were heterogeneous over a narrow time window, providing strong constraints on physical models of sub-Japan Sea mantle development. The nature and origin of this source heterogeneity remains controversial nevertheless. Pouclet and Bellon (this volume) and Nohda et al. (this volume) assumed that substantial gaps in time existed between the generation of relatively depleted and enriched basalts at Sites 794 and 797. Pouclet and Bellon (this volume) used $\mathrm{Nd}$ and $\mathrm{Sr}$ isotopes and geochemical data to suggest that the upper basalts at Site 794 were derived initially from an enriched OIB-type mantle reservoir (continental tholeiite sills associated with the early rifting phase), with the lower (they assume later) basalts derived from a MORB-source depleted mantle associated with upwelling of a deep mantle diapir during continued extension. Nohda et al. (this volume) assumed that the lower, enriched basalts from Site 797 and all units from Site 794 are approximately the same age, and assumed that the depleted, upper basalts from Site 797 are younger than both. They used $\mathrm{Nd}$ and $\mathrm{Sr}$ isotopes and geochemical data to propose that the progression in chemistry thus assumed was due to physical replacement of an enriched subcontinental upper mantle (SCUM) with a depleted asthenospheric mantle (AM) by injection during backarc development (Fig. 7). The two models, although similar in proposing a change in the mantle source from enriched to depleted with time, make opposite assumptions regarding the emplacement history of sills at the different sites.

Cousens and Allan (this volume) used $\mathrm{Sr}, \mathrm{Nd}$, and $\mathrm{Pb}$ isotopes and geochemical data to propose a very different model for the origin of the Yamato Basin rocks. As did Nohda et al. (this volume) and Pouclet et al. (this volume), they noted the extraordinarily well-developed mixing relationships in the isotopic data, most notably in the $\mathrm{Pb}$ isotopes. They modeled the data from both the individual sites and from all three ODP sites as representing derivation from depleted MORB-like mantle sources variously enriched in sediment components during subduction, namely derivation from shallow melting of a heterogeneously enriched arc-related mantle source overlying a subduction zone. They argued that old subcontinental lithosphere or continental crustal contamination during generation and ascent was unlikely, based on published isotopic compositions of the Japanese arc and crustal basement rocks and inference of lithospheric composition from isotopic data on lavas from eastern China. A lack of $\mathrm{Pb}$ data on pertinent samples from the Yamato Rise and Japanese lower crust prevents the ruling out of possible contamination by young, subcontinental lithosphere, although no overt evidence of crustal contamination was found in the cored samples. Contrary to the other models, this model does not support interpretations of large-scale mantle changes during backarc rifting.

\section{CRUSTAL STRUCTURE OF THE JAPAN SEA}

\section{Overview}

Until recently, the crust of the Japan Sea had long been represented by the Ludwig et al. (1975) model, which incorporated the results of U.S. and Japanese seismic studies. In this model, the Japan and Yamato basins possess oceanic crust, whereas the crust beneath the Yamato Rise resembles crust of the Japan arc. A thick sediment is responsible for the shallower than normal seafloor in the sea. Furthermore, the Yamato Basin was thought to have undergone greater modification than the Japan Basin as evidenced by the presence of material exhibiting a wavespeed of $3.5 \mathrm{~km} / \mathrm{s}$, a thicker Layer 3, and low $P_{\mathrm{n}}$ wavespeed.

In 1985, a large-scale detailed seismic investigation using multichannel seismics, ocean bottom seismometers (OBS) with air guns, and explosives as controlled source was carried out in the southern

\section{Cousens and Allan's model}

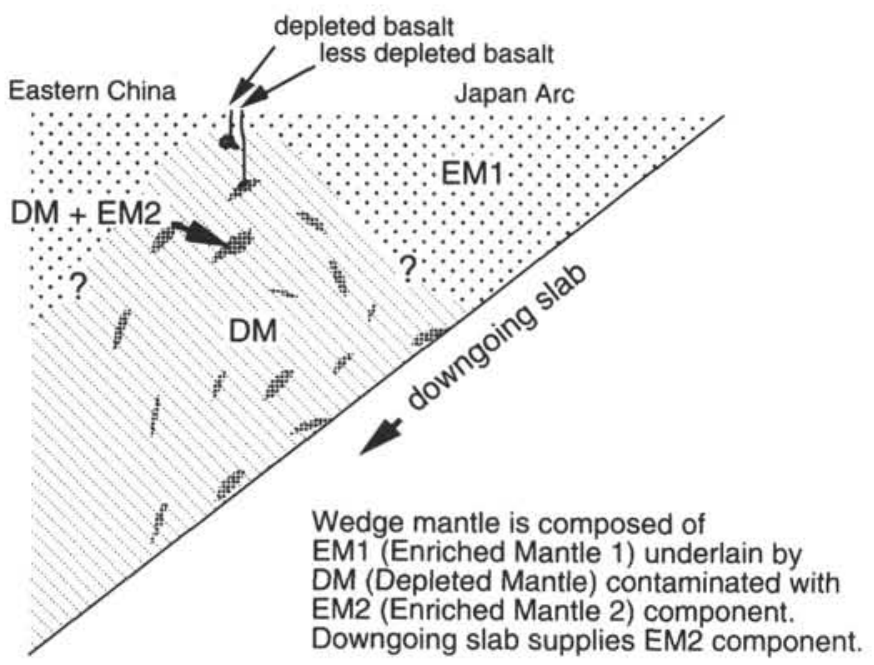

\section{Nohda et al.'s model}

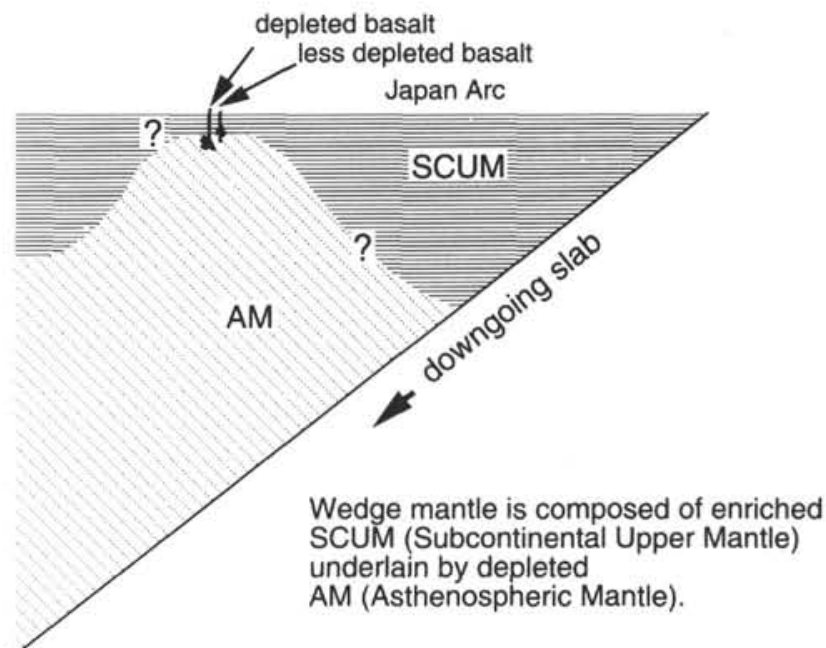

Figure 7. Two comparative models of magma genesis (Cousens and Allan, this volume; Nohda et al., this volume) during the opening of the Japan Sea. 
Yamato Basin (Hirata et al., 1987), from which a number of new findings were presented together with a two-dimensional view of the crust (Katao, 1988; Hirata et al., 1989; Chung et al., 1990). It was shown that both Layers 2 and 3 were thicker than normal beneath the Yamato Basin, and that the $P_{\mathrm{n}}$ wavespeed had an azimuthal dependence and largest in the northwest-southeast direction, approximately perpendicular to the strike of the basin. Previously the $P_{n}$ wavespeed was not well defined and a low value of $7.6 \mathrm{~km} / \mathrm{s}$ has been suggested (Ludwig et al., 1975). The 1985 results showed that the $P_{n}$ had been underestimated, and that it actually ranges between 7.8 and $8.3 \mathrm{~km} / \mathrm{s}$ (Chung et al., 1990).

A detailed controlled-source seismic survey was conducted at Site 794, where an ocean broadband downhole seismometer (OBDS) was installed semi-permanently together with a temporary nine-OBS array (Leg 127 and 128 Shipboard Scientific Parties, 1990). Though smaller in scale than the 1985 experiment, this experiment achieved higher spatial resolution due to three-dimensional spacing of OBS's and OBDS, and navigation accuracy by GPS (Shinohara et al., this volume).

In 1990, a Japan-U.S.S.R. joint geophysical investigation was conducted in the eastern Japan Basin (Hirata et al., 1991). Their results clearly indicate an 8-9 km thick oceanic crust. The $P_{\mathrm{n}}$ wavespeed at the Moho discontinuity ranges between 8.0 and $8.4 \mathrm{~km} / \mathrm{s}$.

Figure 8 incorporates these new data with the classic model of crustal structure beneath the Japan Sea. The following sections summarize our present knowledge of the seismic structure of the Japan Sea and discuss its tectonic significance.

\section{Meaning of $3.5 \mathrm{~km} / \mathrm{s}$ Layer}

The exact wavespeed of the so-called $3.5 \mathrm{~km} / \mathrm{s}$ layer (Ludwig et al., 1975) was not well determined because arrivals from this layer were often late arrivals and could be observed for a short range, and because not all the profiles were reversed. The main feature of the 3.5 $\mathrm{km} / \mathrm{s}$ layer is its low wavespeed in contrast with that of the underlying acoustic basement $(5.8 \mathrm{~km} / \mathrm{s}$ on average). The average thickness of this layer was estimated to be about $1.2 \mathrm{~km}$ in the Yamato Basin. The new OBS data clearly demonstrate that $3.5 \mathrm{~km} / \mathrm{s}$ is not representative of the actual wavespeed structure at the top of Layer 2 (Hirata et al., 1987; Shinohara et al., this volume). These latter detailed seismic refraction records revealed that the wavespeed increases from about 3.0 to $4.5 \mathrm{~km} / \mathrm{s}$ near Site 794 over a thickness of about $300 \mathrm{~m}$, which amounts to $5 \mathrm{~s}^{-1}$ wavespeed gradient (Shinohara et al., this volume). At a depth of $5 \mathrm{~km}$, which is about the bottom of the $3.5 \mathrm{~km} / \mathrm{s}$ layer according to Ludwig et al. (1975), the OBS results indicate a wavespeed well over 4 km/s (Katao, 1988; Chung et al., 1990).

ODP drilling showed that rocks beneath the acoustic basement of the Yamato Basin represent a stack of basalt sills and flows and interbedded sediments (Tamaki, Pisciotto, Allan, et al., 1990). The values of $P$-wavespeed from logging results and physical properties of cores ranged between 4 and $5 \mathrm{~km} / \mathrm{s}$, where resistivity is higher, but are less than $3.5 \mathrm{~km} / \mathrm{s}$ for lower resistivity (Ingle, Suyehiro, von Breymann, et al., 1990). This zone corresponds to the large wavespeed gradient zone noted above.

In the Japan Basin, such a layer of a few hundred meters thickness with a large wavespeed gradient was also identified by OBS data obtained in 1990 (Hirata et al., 1991). We concluded that the $3.5 \mathrm{~km} / \mathrm{s}$ layer is not a discriminating factor of the two basins. Rather, it is a thin layer probably consisting of a sill-and-sediment complex as seen in ODP drilling.

\section{Lower Crust}

Figure 8 illustrates that there is not much difference between the Japan and Yamato basins in terms of Layer 2 thickness and wavespeed. The main difference between these two basins lies in the thickness of Layer 3. The crustal thickness of about $14 \mathrm{~km}$ in the Yamato Basin was interpreted to be either due to magmatic material underplating or intrusion into normal oceanic crust based on the

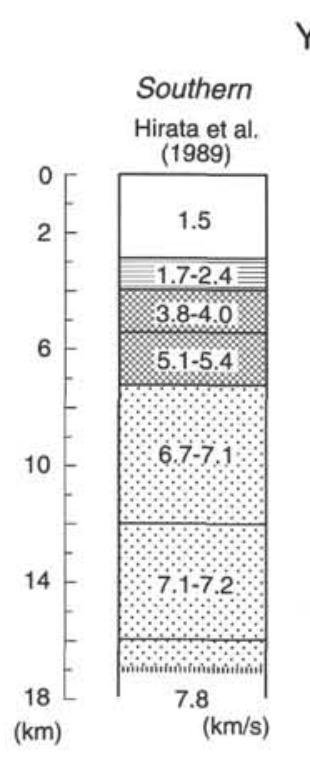

\section{Yamato Basin}

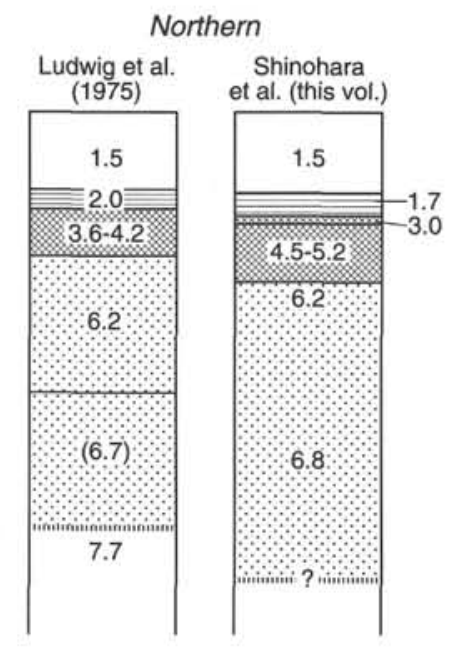

Site 794

\section{Japan Basin}
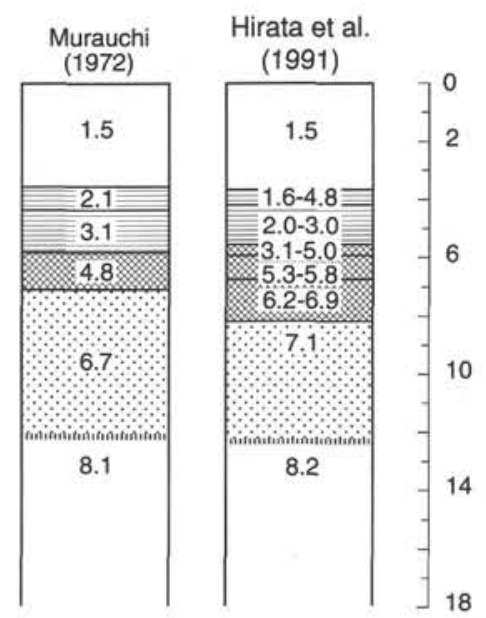

(km)

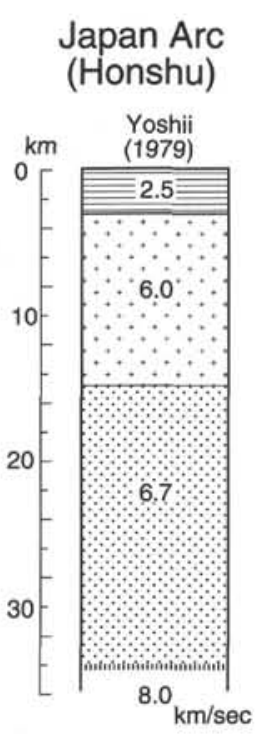

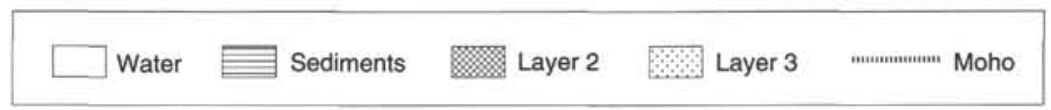

Figure 8. Crustal structure of the Japan Basin and the Yamato Basin (modified from Hirata et al., 1991). 
resemblance of the wavespeed-depth function to that of normal ocean crust (Hirata et al., 1989). Alternatively, Hamano et al. (1989) proposed that the greater crustal thickness might be due to thinning of continental lithosphere in a low temperature regime which would explain the current heat flow and basement depth data as supported by a numerical modeling (Seno et al., 1991) based on the McKenzie model (McKenzie, 1978).

A number of passive margins have been shown to possess a lower crust characterized by a high wavespeed, a feature which is commonly interpreted to be the result of magma intrusion (e.g., White et al., 1987; Tréhu et al., 1989). The characteristic wavespeed is $7.2 \mathrm{~km} / \mathrm{s}$ with a small gradient. In the southern Yamato Basin, the lower crust wavespeed varies between 7.0 and $7.2 \mathrm{~km} / \mathrm{s}$ (Katao, 1988; Chung et al., 1990), which represents a slightly smaller range than found at passive margins.

The thickness and velocity of the lower crust may be controlled by the temperature regime (White et al., 1987; White and McKenzie, 1989). Using the instantaneous lithosphere stretching model by McKenzie (1978), Seno et al. (1991) calculated that the asthenosphere temperature beneath the Japan and Yamato basins is normal at about $1300^{\circ} \mathrm{C}$. In this case, the crustal thickness beneath the Yamato Basin is difficult to be accounted for by magma intrusion alone. However, as the wavespeed is larger than that of the Japan arc lower crust (e.g., Yoshii and Asano, 1972), at least some portion of the lower crust in the Yamato Basin probably consists of added magma, part of which extruded along the Yamato Seamount chain or intruded as sills as evidenced by drilling at Sites 794 and 796 (Tamaki, Pisciotto, Allan, et al., 1990; Ingle, Suyehiro, von Breymann, et al., 1990).

\section{Crustal Anisotropy and Electrical Resistivity}

An electrical resistivity experiment was conducted at Site 794 using an active electric source to study the structure of the upper several kilometers of crust. Data derived from the Site 794 experiments were combined with magnetotelluric measurements indicating a resistive mantle lies beneath the Yamato Basin (Utada, 1987), allowing a higher resolution model of the crust-mantle resistivity structure. The low resistivity layer beneath the sedimentary layer extends to at least $3 \mathrm{~km}$ of depth in the model, whereas the shallower portion matches logging results at this site. Resistivity values range between about 2 and $10 \mathrm{ohm}-\mathrm{m}$ and average about $5 \mathrm{ohm}-\mathrm{m}$ (Hamano et al., this volume). Therefore, this layer either includes or corresponds to the $4.5-5.2 \mathrm{~km} / \mathrm{s}$ layer of Shinohara et al. (this volume).

The low resistivity layer was found to possess seismic anisotropy at least within its upper part; the $P$-wavespeed is $4 \%-7 \%$ faster in east-west (or east-southeast-west-northwest) than in north-south direction. The anisotropic pattern is thought to be due to opening of cracks induced by the present stress field in this area which is a product of ongoing east-west compression (Hirata et al., this volume). The azimuthal dependence of wavespeed is similar to that of $P_{\mathrm{n}}$ wavespeed (Chung et al., 1990). However, the $P_{\mathrm{n}}$ wavespeed variation is probably related to the origin of the Yamato Basin, reflecting the past history.

Since the low resistivity observed down to $3 \mathrm{~km}$ reflects the content and connectivity of seawater (Hamano et al., this volume), the water may be filling the seismically inferred cracks. The resistivity measurements were conducted in two different directions in the hope of detecting anisotropy. Measurements at large horizontal distances displayed no significant azimuthal differences. At shorter distances, which correspond to shallower structure, the scatter in data may not be real and not clear if it was produced by anisotropy (Hamano, pers. comm.). If the proposed cracks are aligned in an approximately east-southeast-west-northwest direction, then resistivity may be expected to be low in this direction. This is not contradicted by the resistivity data obtained at Site 794 .

\section{NEOGENE PATTERN OF SUBSIDENCE AND UPLIFT}

Backstripping and geohistory analyses of five Neogene stratigraphic sequences within the Japan Sea area provide constraints on vertical patterns of crustal motion during evolution of the sea over the past 30 m.y. (Fig. 9) as detailed by Ingle (this volume). Geohistory and backstripping techniques utilize data on variations in age, stratigraphic thickness, paleobathymetry (water depth), and lithology within a given sedimentary column to quantitatively estimate (1) rates of subsidence and/or uplift during deposition of the column and (2) hindcast the burial history of individual stratigraphic horizons within the column including the underlying basement substratum. The combined application of these procedures yields plots or curves of subsidence/uplift which reflect the dynamics of the crust underlying the column and, in turn, the associated processes responsible for basin formation and deformation.

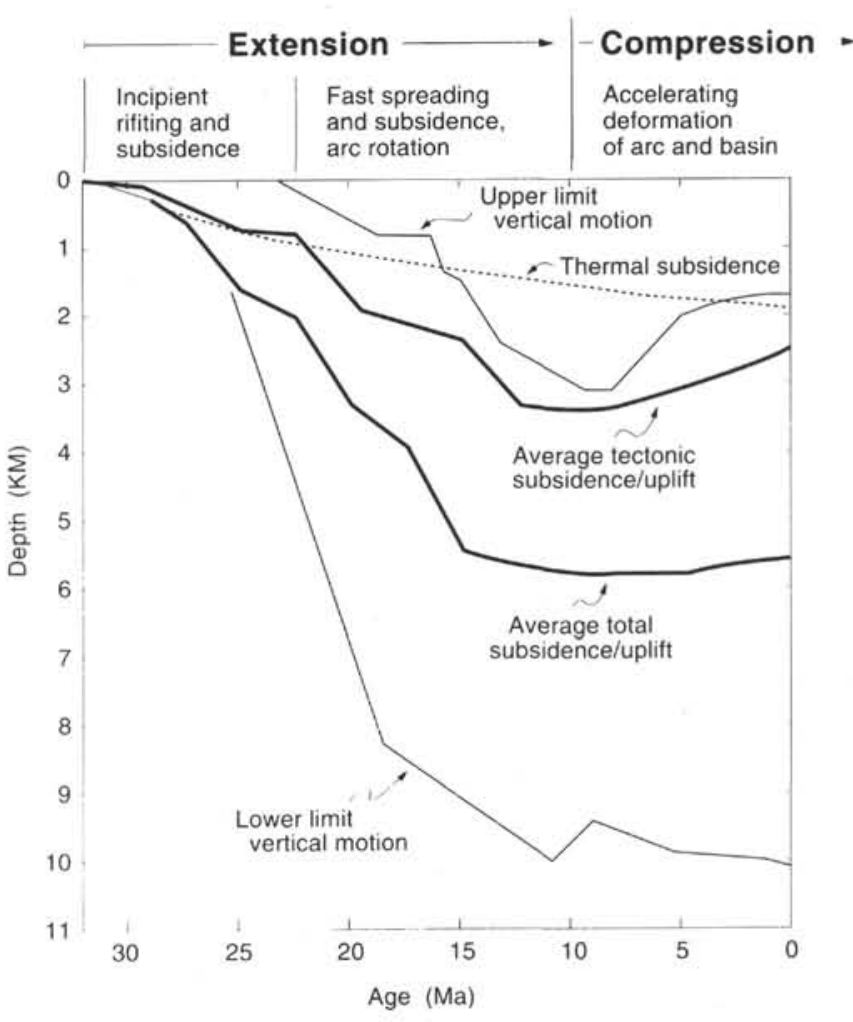

Figure 9. Summary of tectonic (residual) and total subsidence patterns in the Japan Sea backarc area as derived from geohistory and backstripping analysis of five stratigraphic sequences including three onshore sections in Korea, Japan, and Sakhalin Island, U.S.S.R., the offshore Dolgorae well in the Tsushima Basin, and ODP Site 794 at the juncture of the Yamato and Japan basins. The envelope of maximum and minimum limits of vertical motion expresses extremes defined by individual subsidence curves. Curves of average total and tectonic subsidence represent averages calculated for the five sequences analyzed for each $2.5 \mathrm{~m}$.y. interval between $32 \mathrm{Ma}$ and $0 \mathrm{Ma}$. The thermal subsidence curve expresses the relationship between simple lithospheric cooling and the square root of time presented by Parsons and Sclater (1977) with the onset of cooling set at $30 \mathrm{Ma}$. Note that early backarc rifting and subsidence follow the trajectory for thermal subsidence between 32 and $23 \mathrm{Ma}$ with subsequent rates of subsidence between $23 \mathrm{Ma}$ and $13 \mathrm{Ma}$ exceeding thermal effects in turn implying the dominance of mechanical or fault-controlled subsidence. Initial evidence of uplift and assumed onset of compressive deformation occur about $10 \mathrm{Ma}$ and accelerate about $5 \mathrm{Ma}$. 
Variations in lithology and assumed original porosities allow a given sediment column to be sequentially decompacted and sedimentary thicknesses removed or backstripped through time. The backstripping process removes the effects isostatic (Airy) loading induced by sediment accumulation and changes in water depth through time, yielding net or residual rates of subsidence/uplift for successive intervals of time. Residual vertical motion remaining after the effects of loading of the column are removed is assumed to express tectonically induced subsidence and/or uplift. Thus, geohistory and backstripping analysis of a stratigraphic sequence yields (1) a curve of residual or tectonic subsidence and (2) a curve depicting total subsidence representing the cumulative loading effects of sediment accumulation and variations in water depth, together with any tectonically induced subsidence and/or uplift (Fig. 9). The five stratigraphic columns selected for subsidence analysis in the Japan Sea area include, from south to north, the onshore Pohang section in southeastern Korea, the offshore Dolgorae well in the Tsushima Basin (Chough and Barg, 1987), the onshore Oga Peninsula section of northeastern Honshu, Japan, ODP Site 794 at the juncture of the Yamato and Japan basins, and the onshore South Sakhalin/Makarov River section of Sakhalin Island, U.S.S.R., as discussed by Ingle (this volume). The onshore Sakhalin, Oga Peninsula, and Pohang sections are underlain by continental crust, whereas the Dolgorae well and ODP Site 794 are underlain by transitional and quasi-oceanic crust, respectively. Rates of sediment accumulation also differ significantly at these five sites with over $10,000 \mathrm{~m}$ of Neogene sediment penetrated in the Dolgorae well and less than $600 \mathrm{~m}$ of Neogene sediment overlying volcanic basement rocks at ODP Site 794. Despite the major differences in tectonic and depositional settings, paleobathymetric histories, and lithofacies among the five stratigraphic columns analyzed, both total and tectonic subsidence curves for all five columns illustrate similar patterns of subsidence and uplift for the Japan Sea backarc area (Ingle, this volume) providing a useful overview of vertical crustal motion during evolution of the sea.

The collective subsidence history at the five stratigraphic sequences analyzed is summarized on Figure 9 by average curves of total and tectonic subsidence as calculated for each $2.5 \mathrm{~m}$.y. interval between $32 \mathrm{Ma}$ and $0 \mathrm{Ma}$. The envelope of limiting vertical motion is defined by the extremes of each subsidence curve with a curve for simple thermal subsidence plotted for comparison (Fig. 9). Examination of the averaged subsidence histories indicates that extension and subsidence in the Japan Sea backarc area occurred in four stages or phases involving alternating dominance of thermal and fault-controlled subsidence between $32 \mathrm{Ma}$ and about $10 \mathrm{Ma}$, at which point widespread uplift commenced and a compressional regime was initiated which continues to dominate backarc evolution to the present.

Initial rifting and subsidence in the Japan Sea area occurred between $32 \mathrm{Ma}$ and $23 \mathrm{Ma}$ at rates correlative with simple thermal subsidence (Fig. 9) accompanied by widespread deposition of nonmarine sediments and volcaniclastic deposits. This latter juvenile phase in basin evolution was followed by a period of accelerated early Miocene subsidence between $23 \mathrm{Ma}$ and $19 \mathrm{Ma}$ at rates far exceeding those expected for thermal subsidence ( $>900 \mathrm{~m} / \mathrm{m} . \mathrm{y}$.) implying dominance of mechanical or fault-controlled subsidence apparently coincident with fast spreading, backarc extension, and arc-rotation.

As discussed in detail by Ingle (this volume), the period of early Miocene rapid subsidence (23-19 Ma) clearly correlates with (1) the initial appearance of bathyal marine sediments in the backarc area including the oldest marine sediments encountered at ODP Sites 794, 797 , and 799, (2) paleomagnetic evidence of arc rotation, and (3) radiometric ages of basalts and dolerites sampled at the base of ODP Sites 794, 795, and 797; in short, the initial formation of the Japan Sea. Moreover, the rapid rates of subsidence during this latter period match predicted subsidence patterns accompanying initial subsidence in pull-apart basins and hence support the concept of a pull-apart origin for the Japan Sea proposed by Lallemand and Jolivet (1986), and Jolivet et al. (1991).
The tectonic subsidence curve parallels the predicted curve for thermal subsidence between $19 \mathrm{Ma}$ and $15 \mathrm{Ma}$ with a second period of rapid subsidence occurring in the middle Miocene between $15 \mathrm{Ma}$ and $12.5 \mathrm{Ma}$, pointing to the dominance of mechanical or fault-controlled subsidence over thermal subsidence during this time (Fig. 9). A final phase of thermal subsidence occurred between $12.5 \mathrm{Ma}$ and about $10 \mathrm{Ma}$, just prior to the initial indications of uplift which mark the tectonic subsidence curve between about 10-7 Ma in late Miocene time. This latter event apparently signals a major change from an extensional to compressional regime in the Japan Sea area. Rates of uplift accelerated beginning at about $5 \mathrm{Ma}$ with rates of PliocenePleistocene uplift commonly exceeding $500 \mathrm{~m} / \mathrm{m}$.y. as dramatically illustrated by the obduction of the Okushiri Ridge off Hokkaido (Tamaki, Pisciotto, Allan, et al., 1990). The pattern of rapid Quaternary uplift clearly indicated by the average tectonic subsidence/uplift curve (Fig. 9) matches similar rates and patterns of Quaternary uplift previously documented at onshore localities on Honshu (e.g., Sugi et al., 1983) and the widespread evidence of middle Quaternary deformation and topographic reorganization apparent in seismic reflection profiles from the eastern Japan Sea (e.g., Tamaki, 1988).

In summary, geohistory-backstripping analysis of selected onshore and offshore stratigraphic sequences indicates that the evolution of the Japan Sea can be divided into eight phases based on major variations in rates and directions of vertical motion in the backarc area with a fundamental change from an extensional to compressional regime occurring about $10 \mathrm{Ma}$. Discrete evolutionary stages include (1) relatively slow initial thermal subsidence between $32 \mathrm{Ma}$ and $23 \mathrm{Ma}$, (2) rapid subsidence to bathyal water depths apparently accompanied by rapid spreading, backarc extension, and arc rotation between $23 \mathrm{Ma}$ and $19 \mathrm{Ma}$ at rates implying dominance of mechanical or fault-controlled subsidence, (3) slow thermal subsidence between $19 \mathrm{Ma}$ and $15 \mathrm{Ma}$, (4) a second phase of rapid mechanical or fault-controlled subsidence between $15 \mathrm{Ma}$ and $12.5 \mathrm{Ma}$, (5) a return to slow thermal subsidence between $12.5 \mathrm{Ma}$ and $10 \mathrm{Ma},(6)$ initiation of widespread uplift and onset of a compressional regime between $10 \mathrm{Ma}$ and $7 \mathrm{Ma}$, (7) acceleration of uplift and deformation along the margins of the Japan Sea about $5 \mathrm{Ma}$, and (8) major compressional deformation and topographic reorganization of large areas of the Japan Sea and adjacent insular and continental margins accompanied by extremely high rates of uplift $(\sim 500 \mathrm{~m} / \mathrm{m}$.y.) between $2 \mathrm{Ma}$ and $0 \mathrm{Ma}$.

\section{DISCUSSION}

The ages of the basement rocks, the nature of volcanic rocks constituting basement, the crustal structure revealed by geophysical experiments, and the synthesized history of basin subsidence are all equally important in constructing the opening tectonics of the Japan Sea. Figure 10 represents distribution of crustal structure in the Japan Sea. Figure 10 was mapped on the basis of seismic refraction/reflection study, bottom sampling from rises, ridges, and seamounts, topography of the basement and seafloor, magnetic anomalies, and heat flow. The crustal structure in the Russian side of the Japan Sea is still uncertain, but Figure 10 displays the general crustal structure of the Japan Sea for the first time and allows significant characteristics of the Japan Sea crustal distribution to be deduced. The most prominent aspect of crustal structure in the Japan Sea is the wide distribution of thinned crust and the limited distribution of oceanic crust. In addition, the wide distribution of continental crust in the southern Japan Sea (including the Yamato Rise and the Korea Plateau) contrasts markedly with the deep basins of the northern Japan Sea. The areas of rifted continental crust surrounding the blocks of continental crust are characterized by the ubiquitous distribution of the normal faults, which are likely remnants of listric faults formed during the continental extension.

Figure 10 illustrates (1) the broad distribution of the thinned/extended continental crusts beneath the Japan Sea and (2) that oceanic 


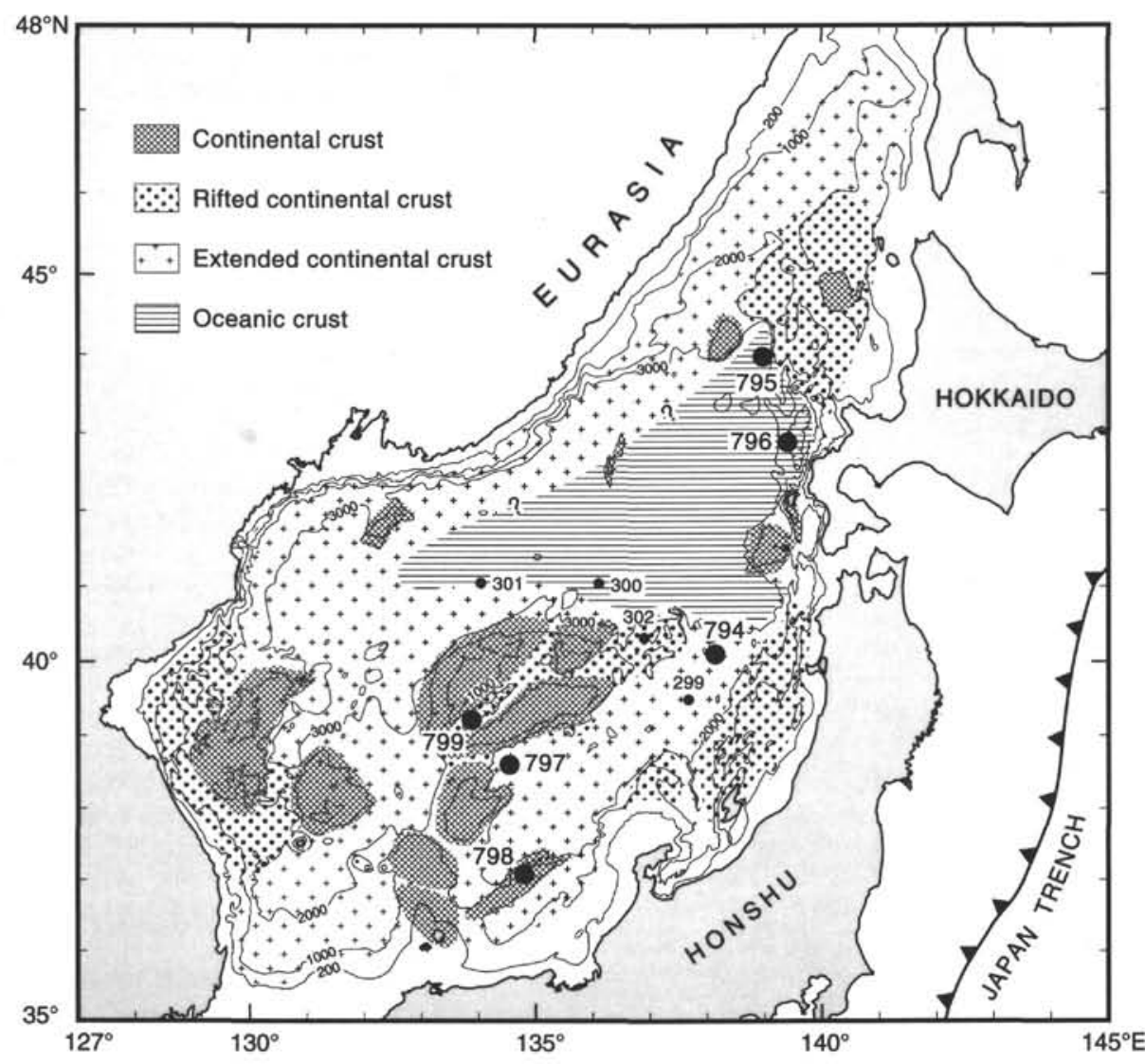

Figure 10. Crustal structure of the Japan Sea. The discrimination of the crustal structure is based on seismic reflection/refraction survey data, bottom sampling data, geomagnetic data, and basement depth and topography.

crust is essentially limited to the eastern part of the Japan Basin. In constructing this map, we classified the anomalously thick crust beneath the Yamato Basin as thinned continental (actually island-arc) crust. Alternatively, it is also possible that the Yamato Basin crust is thickened oceanic crust as suggested by Hirata et al. (1989). In this case, production of anomalously thick oceanic crust calls for associated hotspot activity based upon analogy with the Iceland area where the Iceland hotspot coincides with the Mid-Atlantic Ridge and forms anomalously thick oceanic crust (McKenzie and Bickle, 1988). Present heat flow values do not suggest previous hotspot activity (Langseth and Tamaki, this volume). In fact, Langseth and Tamaki (this volume) show that the heat flow data in the Japan Basin can be explained by a simple cooling model of oceanic lithosphere and that heat flow in the Yamato Basin can be explained by a model invoking stretching of the continental crust. Also, no magnetic anomaly lineations are developed in the Yamato Basin whereas magnetic lineations are unequivocally developed in the Japan Basin (Isezaki, 1986). All of these observations argue against the possibility of seafloor spreading origin of the Yamato Basin with contamination of hotspot activity.

We support the crustal extension origin of the Yamato Basin as first proposed by Hamano et al. (1989). As described in a previous section, the velocities and thicknesses of Layer 2 are essentially the same in the Japan and Yamato basins, whereas the thickness of the Layer 3 (lower crust) in the Yamato Basin is twice as thick as in the Japan Basin (Fig. 8). In addition, the thickness of the lower crust of the Yamato Basin is one-half of the lower crust of the present Japanese island arc which has a comparable wavespeed with that of the Yamato Basin. We assume that the proto-Japan arc crust was originally attached to the Eurasian continent and was initially thicker than the crust now found beneath the modern arc. Given this assumption, and only accounting for extension of the lower crust, the proto-Japan arc crust must have been by a factor of two or more. The upper crust of the Yamato Basin has a wavespeed of about $4.5 \mathrm{~km} / \mathrm{s}$ similar to oceanic Layer 2 and is assumed to be composed of basaltic lava and intrusives as suggested by drilling.

The wavespeed of the upper crust of the present Japan arc is 6.0 $\mathrm{km} / \mathrm{s}$ (Yoshii, 1979) representing typical values for upper continental crust. Because the Yamato Basin apparently lacks a $6.0 \mathrm{~km} / \mathrm{s}$ layer (Fig. 8), we assume that the upper crust which originated from the upper crust of the proto-Japan arc is missing, and that the effusive volcanic rocks overlie the extended lower crust. However, relic portions of the upper crust of the proto-Japan arc remain beneath rises and ridges in the Japan Sea, the areas marked as "continental crust" on Figure 10. The complete elimination of the upper crust and exposure of the lower crust in the Yamato Basin may explain the occurrence of depleted basaltic activity as evidenced by the composition of the upper group of basalts at Site 797.

Seafloor spreading characterized the Japan Basin in contrast to the crustal extension of the Yamato Basin. Tamaki and Kobayashi (1988) temporarily identified magnetic anomaly lineations in the eastern part of the Japan Basin, and they recently confirmed the high possibility of correctness of their temporal identification by using a deep-tow magnetometer (Tamaki, pers. comm.). Based on the most recent anomaly identifications (Shipboard Scientific Party, 1990, fig. 5), the eastern Japan Basin ranges in age from 28 to $18 \mathrm{Ma}$. Heat flow values in the eastern Japan Basin range between 105 and $115 \mathrm{~mW} / \mathrm{m}^{2}$, and are consistent with the interpreted anomaly ages of the seafloor when compared to the age-heat flow relationships established for oceanic lithosphere (Langseth and Tamaki, this volume). Heat flow measurements conducted at all the sites during Legs 127 and 128 demonstrate that the heat transfer is conductive through the upper sedimentary column (Langseth and Tamaki, this volume) and indicate that the 
presently available surface heat flow data base well represents the terrestrial heat flow in the basin as well as the age of the basin formation. The radiometric age of $24 \mathrm{Ma}$ obtained on basement basalts at Site 795 in the northern Japan Basin thus supports inferences from geophysical data despite the lower reliability of the radiometric measurements made on these rocks. The oceanic crust of the eastern Japan Basin may be appreciably older than the basalts dated at Sites 794 and 797 in the Yamato Basin. Kobayashi et al. (1986) and Tamaki and Kobayashi (1988) identified complex pseudofault patterns within the magnetic anomaly lineations of the Japan Basin which suggest frequent rift propagation during the seafloor spreading process. Rift propagation was recently confirmed from additional geomagnetic data which also indicates that propagation was directed to the southwest (Tamaki, pers. comm.).

Jolivet and Tamaki (this volume) suggest that rift propagation initiated at a major strike-slip fault along the eastern margin of the initial Japan Sea (Fig. 11). This model was constructed for the consistent explanation of two key observations; southwestward propagation of the seafloor spreading as recorded in the magnetic anomaly lineation patterns and the eastward-widening distribution of oceanic crust in the Japan Basin (Fig. 10). The model also postulates initial breakup of the lithosphere along the strike-slip fault and subsequent propagation of the breakup by seafloor spreading. Because major strike-slip faults or transform faults represent the weakest zones in the lithosphere (e.g., Mueller and Phillips, 1991), it is plausible to assume that initial breakup of the lithosphere was generated at the strike-slip margin.

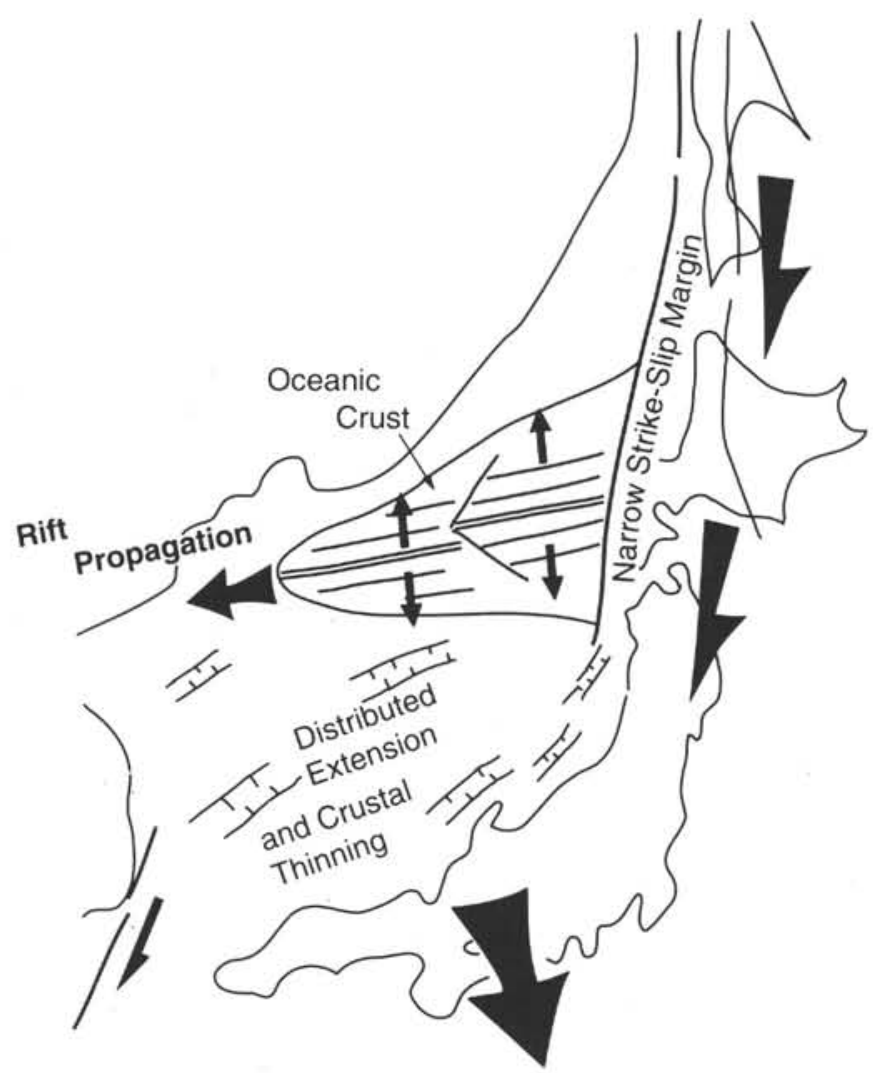

Figure 11. Simplified cartoon of opening of the Japan Sea (modified from Jolivet and Tamaki, this volume). Crustal thinning and extension is prevailed at the initial stage. A seafloor spreading was triggered by the breakup of the lithosphere along the strike-slip margin at the eastern side of the Japan Sea. The spreading center propagated southwestward to increase the area of the oceanic crust. In the meantime the southern Japan Sea was undergoing thinning.
We propose the following scenario of opening of the Japan Sea. Opening was initiated by overall crustal thinning accommodated by two strike-slip margins; the western fault lay along the east coast of the Korean Peninsula and the eastern major fault along the present Okushiri Ridge as suggested by Jolivet and Tamaki (this volume). The breakup of the lithosphere and the generation of oceanic crust by normal seafloor spreading was initiated along a major strike slip fault zone which formed the eastern margin of the juvenile Japan Sea. The spreading process propagated to the southwest into the area of continuing crustal extension and generated a basin floored by oceanic crust (the present Japan Basin) surrounded by a region of thinned island-arc crust region.

According to our model, the apparent difference in age between the basalts recovered at Sites 794 and Site 797 may be significant. Basalts dated at Site 797 are 1-3 m.y. younger than the basalts dated at Site 794, which may reflect the southwestward propagation of the seafloor spreading rift in the present Japan Basin. If spreading was initiated on a transect parallel with the extensional stress trajectory, then crustal thinning would have ceased, and seafloor spreading would have prevailed because the spreading center would have far more easily accommodated the extension. According to this scheme, southwestward propagation of spreading would have shut down the corresponding crustal thinning and associated volcanism, leaving an age gradient in uppermost basement rocks of the extended basin as a remnant signature; this age gradient is documented by the differences in basement ages at Sites 794 and 797. In this scenario, the propagation speed is estimated to have been $10-30 \mathrm{~cm} / \mathrm{yr}$ based on the $1-3$ m.y. age difference and the distance of $300 \mathrm{~km}$ between Site 794 and Site 797. The propagation rate is quite large relative to rates estimated for the mid-oceanic ridges, where the rift propagation and spreading proceed at comparable rates (Hey et al., 1980). The first period of rift propagation in the Japan Sea roughly coincides with the 23-19 Ma rapid subsidence recorded in the surrounding margins following the slow subsidence period (32-23 Ma) (Fig. 9). Rapid rift propagation may have been accommodated by the extremely thinned arc crusts which in turn may have accelerated rift propagation into surrounding areas of thinned crustal zone.

This model is entirely different from the rapid opening model presented by Otofuji and Matsuda (1987). We conclude that opening occurred over a period of 10 m.y. rather than the brief $<1 \mathrm{~m}$.y. period proposed by these authors. The results of ODP drilling clearly contradict the concept of rapid formation of the Japan Sea at about $15 \mathrm{Ma}$. However, the $15 \mathrm{Ma}$ event may express a second phase of extension and subsidence in the backarc area as suggested by the pattern of basin subsidence during this time (Fig. 9) and the evidence of coincident block rotation in southwest Japan (Jolivet and Tamaki, this volume; Kanamori, 1990). Hayashida et al. (1991) proposed a somewhat similar explanation involving simple drift of the arc during early Miocene opening tectonics and subsequent rapid arc rotation about $15 \mathrm{Ma}$. Further syntheses and new data from onshore studies are needed to clarify later Miocene events in the evolution of the Japan Sea.

\section{SUMMARY AND CONCLUSIONS}

Our synthesis of the opening of the Japan Sea combines new results from ODP Leg 127 and 128 with previous onshore and offshore geological and geophysical data. The primary mission of ODP Japan Sea drilling was to establish the age of formation of the sea through dating of basement rocks beneath the Neogene sediment blanket. We penetrated and dated basement rocks at three locations, providing the data needed to reconstruct the opening of the Japan Sea. The Japan Sea was extending from $32 \mathrm{Ma}$ to $10 \mathrm{Ma}$ based on patterns of basin subsidence (Ingle, this volume). However, radioactive dating of basement rocks and the firm identification of magnetic anomalies in oceanic crust of the Japan Sea indicate that the initial opening and formation of the Japan Sea occurred between $28 \mathrm{Ma}$ and $18 \mathrm{Ma}$. 
Extension may have continued in basinal areas after $18 \mathrm{Ma}$ as deduced from subsidence analysis and is suggested by brittle tensional deformation of early to middle Miocene sediments at Sites 794, 798, and 799 (Charvet et al., this volume).

The opening of the Japan Sea was accommodated by the interaction of crustal thinning process and seafloor spreading. Crustal thinning preceded seafloor spreading and likely began at about $32 \mathrm{Ma}$ based on evidence of initial basin subsidence. Seafloor spreading was initiated along a major strike-slip fault zone forming the eastern margin of the juvenile sea and was triggered by deep lithospheric breakup along this fault. Identification of magnetic anomaly lineations and supporting heat flow data suggests seafloor spreading began at $28 \mathrm{Ma}$ in the northeastern Japan Basin at the same time crustal extension was taking place in the southwestern Japan Sea. The interaction between these two processes allowed rapid rift propagation in areas of thin crust. Major opening and volcanism in the Japan Sea appear to have ceased by $18 \mathrm{Ma}$, based on two observations: (1) volcanic rocks definitely younger than 18 Ma were not recovered in basement sequences at Sites 794, 795, and 797, and (2) no magnetic anomaly lineations younger than 18 Ma have been identified in the Japan Sea.

We conclude that crustal thinning, initiation of rifting at the eastern strike-slip margin, and subsequent rift propagation were the fundamental processes dominating the opening tectonics of the Japan Sea. Recently Hawkins et al. (1991) identified a similar dual process involving interaction between crustal thinning and rift propagation to explain the origin of the Lau basin based on the results of ODP Leg 135 drilling in this basin. The crustal thinning-rift propagation couple may represent a common and fundamental process of backarc basin formation. Since the crustal thinning and condition of island arcs is fundamentally different from that of continents, it is necessary to model and simulate the backarc basin formation process independently from the established continental thinning and breakup model (e.g., Yamaji, 1990). The results from ODP Legs 127 and 128 can be expected to further increase in importance as more sophisticated analyses of backarc basin formation are undertaken.

\section{ACKNOWLEDGMENTS}

We thank the captains and crews of JOIDES Resolution and the staff of the Ocean Drilling Program for their assistance in making this project a success. We thank the U.S. National Science Foundation, the Ministry of Education of Japan, and equivalent agencies in Australia, Canada, the European Science Foundation, France, Germany, and United Kingdom for their support of the Ocean Drilling Program. We also thank many Japanese scientists who undertook a large number of site survey cruises in preparation for Legs 127 and 128. Y. Ogawa, S. Maruyama, and M. McWilliams are thanked for their critical review of the manuscript and helpful comments. S. Yamashita is thanked for his comments and for preparing Figure 7. Discussion with R. Tada was helpful in synthesizing stratigraphy of the Japan Sea.

\section{REFERENCES}

Chough, S.K., and Barg, E., 1987. Tectonic history of Ulleung basin margin, East Sea (Sea of Japan). Geology, 15:45-48.

Chung, T.W., Hirata, N., and Sato, R., 1990. Two-dimensional P-and S-wave velocity structure of the Yamato Basin the southeastern Japan Sea, from refraction data collected by an ocean bottom seismographic array. J. Phys. Earth, 38:99-147.

Curray, J.R., Moore, D.G., et al., 1982. Init. Repts. DSDP, 64: Washington (U.S. Govt. Printing Office).

Ernewein, M., Pearce, J.A., Bloomer, S.H., Parson, L.M., Murton, B.J., and Johnson, L.E., in press. Geochemistry of Lau Basin volcanic rocks: influence of ridge sedimentation and arc proximity. Contrib. Mineral. Petrol.
Gibson, I.L., and Saunders, A., 1990. Distinguishing lavas and sills in submarine sequences. Progr. Abstract Geol. Assoc. Canada-Mineral. Assoc. Canada Annual Meeting, 15:A46.

Hamano, Y., Utada, H., and Segawa, J., 1989. Electrical conductivity structure and origin of the Yamato Basin. Abstract 85th Mtg. Soc. Geomagn. Earth, Planetary and Space Sci., III-8.

Hart, S.R., 1988. Heterogeneous mantle domains: signatures, genesis and mixing chronologies. Earth Planet. Sci. Lett., 90:273-296.

Hawkins, J.W., Lonsdale, P.F., Macdougall, J.D., and Volpe, A.M., 1990. Petrology of the axial ridge of the Mariana Trough backarc spreading center. Earth Planet. Sci. Lett., 100:226-250.

Hawkins, J.W., and Melchior, J.T., 1985. Petrology of Mariana Trough and Lau Basin basalts. J. Geophys. Res., 90:11431-11468.

Hawkins, J.W., Parson, L., Allan, J., and Leg 135 Scientific Party, 1991. New insight to the evolution of arc-backarc systems, results of Ocean Drilling Program (ODP) Leg 135, Lau-Tonga ridge transect. Eos, 72:541.

Hayashida, A., Fukui, T., and Torii, M., 1991. Paleomagnetism of the early Miocene Kani Group in southwest Japan and its implication for the opening of the Japan Sea. Geophys. Res. Lett., 18:1095-1096.

Hey, R., Duennebier, F.K., and Morgan, W.J., 1980. Propagating rifts on midocean ridges. J. Geophys. Res., 85:3647-3658.

Hirata, N., Karp, B.Y., Yamaguchi, T., Kanazawa, T., Suyehiro, K., Kasahara, J., Shiobara, H., Shinohara, M., Koresawa, S., and Kinoshita, H., 1991. Seismic structure of the Japan basin in the Japan Sea by the 1990 JapanUSSR expedition. Abstract, IUGG 20th Symp., U11.

Hirata, N., Kinoshita, H., Suyehiro, K., Suyemasu, M., Matsuda, N., Ouchi, T., Katao, H., Koresawa, S., and Nagumo, S., 1987. Report on DELP 1985 cruises in the Japan Sea, Part II: Seismic refraction experiment conducted in the Yamato Basin, southeast Japan Sea. Tokyo Daigaku Jishin Kenkyusho Iho, 62:347-365.

Hirata, N., Tokuyama, H., and Chung, T.W., 1989. An anomalously thick layering of the crust of the Yamato Basin, southeastern Sea of Japan: the final stage of back-arc spreading. Tectonophys., 165:303-314.

Ingle, J.C., Jr., Suyehiro, K., von Breymann, M.T., et al., 1990. Proc. ODP, Init. Repts., 128: College Station, TX (Ocean Drilling Program).

Isezaki, N., 1986. A magnetic anomaly map of the Japan Sea. J. Geomagn. Geoelectr., 38:403-410.

Jolivet, L., Huchon, P., Brun, JP., Le Pichon, X., Chamot-.Rooke, N., and Thomas, J.C., 1991. Arc deformation and marginal basin opening: Japan Sea as a case study. J. Geophys. Res., 96:4367-4384.

Kanaori, Y., 1990. Late Mesozoic - Cenozoic strike-slip and block rotation in the inner belt of southwest Japan. Tectonophysics, 177:381-399.

Kaneoka, L., 1986. Constraints on the time of the evolution of the Japan Sea floor based on radiometric ages. J. Geomagn. Geoelectr.. 38:475-485. 1990. Radiometric age and $\mathrm{Sr}$ isotope characteristics of volcanic rocks from the Japan Sea floor. Geochem. J., 24:7-19.

Kaneoka, I., Miyashita, S., and Tokuyama, H., 1991. ${ }^{40} \mathrm{Ar}-{ }^{39} \mathrm{Ar}$ ages of volcanic rocks recovered from the Okushiri Ridge, Japan Sea-remained problems concerning the period of the opening of the Japan Sea. Abstract Autumn Meeting Volcanol. Soc. Jpn., 1991-2:110. (in Japanese)

Karig, D.E., Ingle, J.C., Jr., et al., 1975. Init. Repts. DSDP, 31: Washington (U.S. Govt. Printing Office).

Katao, H., 1988. Seismic structure and formation of the Yamato Basin. Tokyo Daigaku Jishin Kenkyusho Iho, 63:51-86.

Kobayashi, K., Tamaki, K., Nakanishi, M., Isezaki, N., and Sayanagi, K., 1986. Complex pseudofault pattern of the Japan Sea-results of detailed geomagnetic survey. Eos, 67:1227.

Lallemand, S., and Jolivet, L., 1986. Japan Sea: a pull-apart basin? Earth Planet. Sci. Lett., 76:375-389.

Leg 127 and Leg 128 Shipboard Scientific Parties, 1990. Evolution of the Japan Sea. Nature, 346:18-20.

Ludwig, W.J., Murauchi, S., and Houtz, R.E., 1975. Sediments and structure of the Japan Sea. Geol. Soc. Am. Bull., 86:651-664.

McKenzie, D., 1978. Some remarks on the development of sedimentary basins. Earth Planet. Sci. Lett., 40:25-32.

McKenzie, D., and Bickle, M.J., 1988. The volume and composition of melt generated by extension of the lithosphere. J. Petrol., 29:625-679.

Mueller, S., and Phillips, R.J., 1991. On the initiation of subduction. J. Geophys. Res., 96:651-665.

Murauchi, S., 1972. Crustal structure in the Sea of Japan from seismic exploration. Kagaku, 42:367-375. (in Japanese) 
ODP Leg 139 Scientific Drilling Party, 1992. Hot rocks and masive sulfide: northern Juan de Fuca Ridge. Eos, 73:193-198.

Otofuji, Y., and Matsuda, T., 1983. Paleomagnetic evidence for the clockwise rotation of Southwest Japan. Earth Planet. Sci. Lett., 62:349-359.

, 1987. Amount of clockwise rotation of southwest Japan-fan shape opening of the southwestern part of the Japan Sea. Earth Planet. Sci. Lett., 85:289-301.

Parsons, B., and Sclater, J.G., 1977. An analysis of the variation of ocean floor bathymetry and heat flow with age. J. Geophys. Res., 82:803-827.

Pearce, J.A., 1982. Trace element characteristics of lavas from destructive plate boundaries. In Thorpe, R.S. (Ed.), Andesites: Orogenic Andesites and Related Rocks: Chichester (Wiley), 525-548.

Pearce, J.A., Alabaster, T., Shelton, A.W., and Searle, M.P., 1981. The Oman ophiolite as a Cretaceous arc-basin complex: evidence and implications. Philos. Trans R. Soc. London A, 300:299-317.

Saunders, A.D., Fornari, D.J., Joron, J.-L., Tarney, J., and Treuil, M., 1982. Geochemistry of basic igneous rocks, Gulf of California, Deep Sea Drilling Project Leg 64. In Curray, J.R., Moore, D.G., et al. (Eds.), Init. Repts. DSDP, 64: Washington (U.S. Govt. Printing Office), 595-642.

Saunders, A.D., and Tarney, J., 1984. Geochemical characteristics of basaltic volcanism within back-arc basins. In Kokelaar, B.P., and Howells, M.F. (Eds.), Marginal Basin Geology: London (Blackwell), 59-76.

Seno, T., Hamano, Y., and Yamano, M., 1991. Basin stretching modelling of Yamato Basin, Japan Sea. Chikyu Extra, 3:145-149. (in Japanese)

Shipboard Scientific Party, 1990. Background, objectives, and principal results, ODP Leg 127, Japan Sea. In Tamaki, K., Pisciotto, K., Allan, J., et al., Proc. ODP, Init. Repts., 127: College Station, TX (Ocean Drilling Program), 5-33,

Sugi, N., Chinzei, K., and Uyeda, S., 1983. Vertical crustal movements of northeast Japan since Middle Miocene. In Hilde, T.W., and Uyeda, S. (Eds.), Geodynamics of the Western Pacific-Indonesian Region. Am. Geophys. Union, Geodyn. Ser., 11:317-329.

Sun, S.S., Nesbitt, R.W., and Sharaskin, A.Y., 1979. Geochemical characteristics of mid-ocean ridge basalts. Earth Planet. Sci. Lett., 44:119-138.

Tamaki, K., 1986. Age estimation of the Japan Sea on the basis of stratigraphy, basement depth, and heat flow data. J. Geomagn. Geoelectr., 38:427-446. -1988. Geological structure of the Japan Sea and its tectonic implications. Bull. Geol. Surv. Jpn., 39:269-365.

Tamaki, K., and Honza, E., 1985. Incipient subduction and obduction along the eastern margin of the Japan Sea. Tectonophysics, 119:381-406.

Tamaki, K., and Kobayashi, K., 1988. Geomagnetic anomaly lineation in the Japan Sea. Mar. Sci. Monthly, 20:705-710. (in Japanese)

, 1991. Global tectonics and formation of marginal basins: a role of the western Pacific. Episodes, 14:224-230.

Tamaki, K., Pisciotto, K., Allan, J., et al., 1990. Proc. ODP, Init. Repts., 127: College Station, TX (Ocean Drilling Program).
Tosha, T., and Hamano, Y., 1988. Paleomagnetism of Tertiary rocks from the Oga Peninsula and the rotation of northeastern Japan. Tectonics, 7:653-662.

Tréhu, A., Ballard, A., Dorman, L.M., Gettrust, J.F., Klitgord, K.D., and Schreiner, A., 1989. Structure of the lower crust beneath the Carolina Trough, U.S. Atlantic continental margin. J. Geophys. Res., 94:10585-10600.

Tsuchiya, N., 1988. Distribution and chemical composition of the middle Miocene basaltic rocks in Akita-Yamagata oil fields of Northeastern Japan. Bull. Geol. Soc. Jpn., 94:591-608.

1989. Submarine basalt volcanism of Miocene Aosawa Formation in the Akita-Yamagata oil field basin, back-arc region of Northeast Japan. Mem.-Geol. Soc. Japan, 32:399-408.

, 1990. Middle Miocene back-arc rift magmatism of basalt in the NE Japan arc. Bull. Geol. Soc. Jpn., 41:473-505.

Utada, H., 1987. A direct inversion method for two-dimensional modeling in the geomagnetic induction problem [Ph.D. dissert.]. Univ. of Tokyo.

Volpe, A.M., Macdougall, J.D., and Hawkins, J.W., 1987. Mariana Trough Basalts (MTB): trace element and $\mathrm{Sr}-\mathrm{Nd}$ isotopic evidence for between MORB-like and arc-like melts. Earth Planet. Sci. Lett., 82:241-254.

White, R.S., and McKenzie, D.P., 1989. Magmatism at rift zones: the generation of volcanic continental margins and flood basalts. J. Geophys. Res., 94:7685-7729.

White, R.S., Spence, G.D., Fowler, S.R., McKenzie, D.P., Westbrook, G.K., and Bowen, A.N., 1987. Magmatism at rifted continental margins. Nature, 330:439-444.

Wilson, M., 1989. Igneous Petrogenesis: London (Unwin Hyman).

Yamaji, A., 1990. Rapid intra-arc rifting in Miocene northeast Japan. Tectonics, 9:365-378.

Yamano, M., 1985. Heat flow in the ocean basins and margins. In Nairn, A.E.M., Stehli, F.G., and Uyeda, S. (Eds.), The Ocean Basins and Margins (Vol. 7B): New York (Plenum), 523-557.

Yamazaki, T., 1989. Paleomagnetism of Miocene sedimentary rocks around Matsushima Bay, Northeast Japan and its implication for the time of the rotation of northeast Japan. J. Geomagn. Geoelectr., 41:533-548.

Yoshii, T., 1979. Crustal Structure of Japan: Tokyo (Univ. Tokyo Press) (in Japanese).

Yoshii, T., and Asano, S., 1972. Time-term analyses of explosion seismic data. J. Phys. Earth, 20:47-57.

Zindler, A., and Hart, S.R., 1986. Chemical geodynamics. Annu. Rev. Earth Planet. Sci., 14:493-571.

Date of initial receipt:7 February 1992

Date of acceptance: 23 April 1992

Ms 127/128B-240 